\title{
Sociedad mundial y democracia
}

\author{
Jordi Corominas
}

\section{Resumen}

En este artículo, el autor da por sentado que nos hallamos no sólo en un sistema económico mundial, sino en una única sociedad mundial, la cual genera disparidades cada vez más profundas entre los seres humanos y experimenta la contradicción entre un régimen mundial fuera de todo control democrático y con un extraordinario poder para defender los intereses económicos, políticos y culturales de un pequeño fragmento de la humanidad, y la pervivencia de un cierto debate y juego político democrático dentro de los estados-nación con cada vez menos poder para incidir en las cuestiones más vitales (aire que se respira, comida, salud, educación, vestir) de los ciudadanos inscritos en sus fronteras.

"Ubi societas, ibi ius"

En este artículo, el autor da por sentado que nos hallamos no sólo en un sistema económico mundial, sino en una única sociedad mundial. En la actualidad, las acciones cotidianas y las formas de vida de cada uno, anteriormente a la cultura y al universo simbólico de cada cual, están lastradas y forman sistemas con acontecimientos que ocurren en el otro lado del planeta y con formas de vida absolutamente dispares. Es precisamente la constatación del hecho actual, de que no hay acción hu- mana alguna que no esté afectada por una estructuración mundial de las formas de vida, la que nos lleva a afirmar que la sociedad hoy es mundial. La mayoría de las teorías sociales al uso parecen compartir el prejuicio hegeliano que, al concebir la unidad social como una unidad de semejanza o de identidad y no como una unidad sistémica, considera que sólo los vínculos intraestatales son verdaderamente sociales, mientras que los vínculos "externos" serían propios de una estado de naturaleza (Hobbes) y no de una sociedad propiamente dicha'.

1. Para una comprensión clara del hecho que vivimos en una sociedad mundial, una conceplualización de la misma y la discusión con otros planteamientos puede verse la siguiente bibliografía: A. González, Un solo Mundo, la relevancia de Zubiri para la teoría social, tesis doctoral, Comillas, Madrid, 1995. A. Giddens, La constitución 
Mientras una minoría de la humanidad se encuentra en su casa en cualquier capital del mundo con sus cadenas de hoteles mundiales, sus centros de compras y sus barrios residenciales, la mayoría - de la humanidad vive en una situación muy parecida a la de los salvadoreños de barrios marginales. Su marginación es una necesidad para mantener la jerarquía de la sociedad mundial. No es cierto, como a veces se dice, que los pobres no estén afectados por la globalización. Al contrario, probablemente sean ellos los más profundamente afectados por un sistema económico-político mundial que parece tener la necesidad de la exclusión y la radical heterogeneidad económica de la población para mantenerse como tal. La sociedad mundial genera dịsparidades cada vez más profundas entre los seres humanos y experimenta -con más fuerza cada día - la contradicción entre un régimen mundial fuera de todo control democrático y con un extraordinario poder para defender los intereses económicos, políticos y culturales de un pequeño fragmento de la humanidad, y la pervivencia de un cierto debate y juego político democrático dentro de los estados-nación con cada vez menos poder para incidir en las cuestiones más vitales (aire que se respira, comida, salud, educación, vestir) de los ciudadanos inscritos en sus fronteras. La existencia de un sistema económico mundial y de un proceso de mundialización más allá del marco de los estados no es nada nueva. Ya Marx aprecia en el manifiesto comunista de 1848 , la estrechez que supone para los obreros luchar en un marco nacional ante el establecimiento de un mercado global. Lo nuevo es que, después de la guerra fría, los problemas globales aparecen más claramente como un problema importante en las agendas políticas, y esta perspectiva global cuestiona o replantea un sinfín de términos, mitos y teorías al uso tanto en ética como en filosofía social y política. Una apreciación del último Informe del Desarrollo Humano (1999), completada con algunas de las estadísticas del almanaque mundial del 2000 , resulta ilustrativo al respecto.

\section{Datos que caracterizan la gestión de la so- ciedad mundial actual}

Los datos que destaco a continuación son los que creo que muestran más paladinamente la necesidad de una gestión política mundial de la sociedad. Estos datos no son algo dado, sino producto de la acción humana. Por eso hablo de gestión. Puede ser que no haya un plan consciente de gestión de la sociedad mundial y que con las mejores intenciones se alcancen los resultados que enumero a continuación. El enjuiciamiento moral de los actos humanos es siempre algo más oscuro de la ya por sí difícil y problemática constatación de los resultados de nuestras acciones. En cualquier caso, es importante apreciar que lo que a menudo es atribuido a la suerte, al destino, al azar, o a los dioses, tiene su origen en la organización de la actividad humana.

En la gestión económica se observa un grave crecimiento de la desigualdad norte-sur. A finales del siglo XX, la quinta parte de personas del mundo (1 200 millones) poseen el 86 por ciento del PIB, el 82 por ciento de los mercados de exportación, el 68 por ciento de las inversiones extranjeras directas y el 74 por ciento de las líneas telefónicas mundiales; mientras la quinta parte posee cerca del 1 por ciento en cada sector. Mil doscientos millones de seres humanos disponen de menos de un dólar diario para sobrevivir. La diferencia entre la quinta parte de la población más rica del mundo y la quinta parte más pobre, aumentó de 30 a 1 , en 1960 , a 74 a 1 , en 1997 . Los países de la OCDE, que tan sólo tienen un 19 por ciento de la población global, dominan el 71 por ciento del comercio global en bienes y servicios, el 58 por ciento de inversión directa extranjera y el 91 por ciento del uso de Internet. Las 200 personas más ricas del mundo han más que doblado su renta neta en los 4 años anteriores a 1998, y los haberes de los tres máximos billonarios son superiores al PNB combinado de los 600 millones de personas más pobres. Mientras la renta per cápita media de los países ricos está por encima de los 15000 dólares,

de la sociedad, Amorrortu editores, Argentina, 1995. Diferentes implicaciones de este hecho pueden apreciarse en: J. Corominas, "La acción humana, reproducción y transformación del sistema social mundial" Diakonía, 78, junio, Nicaragua, 1996, pp. 25-40; J., Corominas, "Nacionalismo y sociedad mundial", Nicaragua en busca de su identidad, UCA, Managua, Nicaragua, 1995, pp. 219-241; J. Corominas, "Diversidad de culturas, igualdad de derechos", pp. 629-641, ECA, julio-agosto, 1999. 
los treinta y seis países más pobres del planeta, que concentran la mitad de la población mundial, no alcanzan una renta de 425 dólares per cápita; y los setenta y ocho países de la periferia, incluyendo a los anteriores, con las cuatro quintas partes de la población del planeta, está por debajo de los 2000 dólares per cápita de renta nacional ${ }^{2}$.

Esta desigualdad no significa que unos se "desarrollen" muchísimo más que otros. El informe sobre el desarrollo humano de 1999 observa un movimiento claro hacia un mayor subdesarrollo y miseria de una buena parte de la humanidad: El hogar africano medio de hoy consume el 20 por ciento menos que hace 25 años. De los $4400 \mathrm{mi}$ llones de habitantes del mundo en desarrollo, casi tres quintas partes carecen de saneamiento básico. Casi un tercio no tiene acceso a agua limpia y la cuarta parte no tiene vivienda adecuada. En América Latina existen 98 millones de indigentes, esto es, en la extrema pobreza o "excluidos", que no son tenidos en cuenta ni como mano de obra barata para explotar. El continuo crecimiento económico de los países ricos tampoco redunda en una mayor riqueza para todos sus ciudadanos ni en más empleo. Entre el 7 y el 17 por ciento de la población de los países industrializados es pobre (cien millones de habitantes por debajo del poder adquisitivo considerado mínimo en cada país). El 1 por ciento de las familias más ricas de Estados Unidos (834 000) acumula la misma riqueza que el 90 por ciento del estrato inferior ( 84 millones de familias). A pesar del crecimiento sostenido de los países ricos en las dos últimas décadas, el desempleo se ha mantenido estable.
El sistema político de naciones-estado actual parece muy apto para el aumento de beneficios de aquellas empresas y negocios que consiguen eludir los impuestos del propio pais y exportar puestos de trabajo donde haya costes laborales más bajos y mejores condiciones fiscales. Las maquilas son un ejemplo concreto de explotación de empresas transnacionales, que encuentran así un modo de eludir los códigos éticos y laborales de sus comunidades de origen condenando, además, a los países pobres a mantener los salarios bajos para ser competitivos con otros países más pobres. Se puede también contratar mano de obra más barata en otros países a través de Intemet sin necesidad, siquiera, de salir del país o de invertir en el extranjero". Algunas personas en el mundo pueden invertir su dinero en el país que les ofrece los mejores intereses, producir en el país que los costes salariales sean más bajos, residir en el país donde haya más seguridad y beneficios públicos (educación, salud, etc.) y hacer la declaración fiscal en el país con menos cargas impositivas.

La soberanía fiscal ligada al territorio estatal es cada vez más ficticia para los más ricos. En Alemania, los beneficios de las empresas han aumentado, desde 1979, en un 70 por ciento, mientras que los salarios sólo lo han hecho en un 6 por ciento. Pero los ingresos fiscales procedentes de los salarios se han duplicado en los últimos diez años, mientras que los ingresos fiscales por actividades empresariales se han reducido a la mitad. Pocos estados pueden hoy permanecer al margen del chantaje económico de las grandes corporaciones mundiales ${ }^{4}$. Treinta y siete mil sociedades transnacionales de origen

2. Foro Ignacio Ellacuria, La globalización y sus excluidos, Ed. Verbo Divino, 1999, p. 16 y ss.

3. En el aeropuerto berlinés, por ejemplo, la megafonía es operada desde California donde los costes salariales son mucho más baratos.

4. Un ejemplo de ese poder se revela en la declaración del embajador sueco Lars Anell ante la Unión Europea: "Las empresas Volvo y Ericsson nos amenazan con invertir 50000 millones de coronas en el próximo lustro fuera de Suecia, si el país no se integra a la Unión Europea. ¿Qué podemos hacer? Suecia necesita a Ericsson. Ericsson no necesita a Suecia", Internacional Herald Tribune, 15, 10, 1994. 
europeo, americano o japonés se encuentran en condiciones de utilizar los Estados en contra de ellos mismos para conseguir pactos globales y castigarlos cuando se muestran poco amigos de sus inversiones. Estados Unidos, Japón, Francia, Alemania y Reino Unido se reparten 172 de las doscientas mayores sociedades transnacionales. Su participación en el producto mundial bruto es del 26.8 por ciento. La General Motors tiene unas ventas superiores al PIB de estados como Turquía o Dinamarca. Estas corporaciones mundiales, presentes en todos los mercados, no están sujetas a ningún control político ni a ninguna auditoría mundial. Pueden, por ejemplo, contratar mano de obra infantil en países pobres.

La actual estructura política de naciones-estado permite la existencia de un mercado financiero mundial, en el que el 80 por ciento de las transacciones corresponden a movimientos especulativos de corto plazo. Cinco mil millones de dólares dan la vuelta al mundo cada 25 horas. Todo este volumen inmenso entra, sale, se reasigna y se decide por voluntades que no tienen nada que ver con debates públicos y democráticos. La lógica de estos movimientos es la reproducción del dinero a través del dinero y no la creación de riqueza, y es decisivo, para mantener las ganancias fáciles y rápidas, que no haya poder público ni control alguno que se ejerza sobre estas transacciones. El dinero circulante corresponde cada vez menos a un real aumento de las riquezas económicas. Por otro lado, el sistema de naciones-estado no puede evitar la descomposición de las barreras locales y nacionales en la fijación de normas y aspiraciones sociales al consumo. Existen productos globales que se reconocen y se venden en todo el planeta: McDonald's, Coca-cola, Disney, Kodak, Gillet,
Levis, Microsoft, Malboro. La investigación de mercados determina la existencia de "élites mundiales" y "clases medias mundiales" que siguen los mismos estilos de consumo, mostrando preferencias por "marcas mundiales". Existen los "adolescentes mundiales" que habitan un "espacio mundial", un mundo único de cultura pop, empapándose de los mismos videos, muñecos y música y constituyendo un mercado enorme.

En la gestión poblacional destaca el aumento anual del turismo (de 260 millones, en 1980, a 590 millones, en 1996) y las migraciones. Se estima que unos 145 millones de personas viven fuera de su país. En 1985 eran 104 millones y en 1975, 84 millones. Esta estimación incluye sólo los emigrantes legalmente registrados. Se calcula que en Estados Unidos hay 4 millones de ilegales y que cruzan sus fronteras unos 300000 cada años. Las limitaciones a la migración y a la libre circulación de la mano de obra suponen, para los países pobres, unas pérdidas de 500 mil millones de dólares al año. Las remesas familiares, que constituyen uno de los ingresos más importantes de los países pobres, sólo alcanzan los 58 mil millones de dólares. Sin embargo, a pesar de las duras restricciones de la emigración, la UE necesitará, de mantenerse la actual tasa de fecundidad, 5,3 millones de inmigrantes anuales hasta el 2025 para mantener los actuales niveles de ocupación y la correlación actual entre población ocupada e inactiva. Actualmente, Italia y Japón, con 40,2 años, comparten la primera posición en la edad promedio más alta del mundo. En el 2050, España tendrá la edad media más alta del mundo, 54,3 años. Es por ello que la UE tendrá que acoger más de 35 millones de inmigranles que suplan las bajas laborales registradas y otros

5. Uno de los negocios más lucrativos de la socicdad mundial actual es el tráfico ilegal de cmigrantes. Introducirse ilegalmente de China a Estados Unidos cuesta unos 35000 dólares, de El Salvador unos 5000 dólares. Los traficantes de ilegales mueven unos 4 millones de personas al año generando unos beneficios de 7 mil millones de dólares. En 1998 se recogicron en España más de 1000 mucrtos de "pateras". 
123 millones complementarios si se quiere que por cada habitante jubilado sigan existiendo cuatro o cinco ocupados. En Estados Unidos, en 150 millones de inmigrantes se cifran sus necesidades de mano de obra para los próximos 25 años. También, en algunos países ricos, se percibe una velada actitud xenófoba en la promoción de políticas antinatalistas en el sur, mientras se promueven políticas natalistas en su interior.

La gestión de la salud física y emocional no consigue evitar que sigan muriendo 35000 niños cada día por enfermedades fáciles de prevenir o curar, como la neumonía, diarrea, malaria, tétanos, viruela y la tuberculosis y el cólera que han reaparecido con fuerza en América Latina. Para nueve países de África se pronostica una pérdida de 17 años de expectativa de vida para el 2010, bajando a los niveles de los años sesenta. Tampoco consigue evitar, en los países ricos, el aumento del consumo de antidepresivos y de enfermedades con un fuerte componente social: anorexia, depresión, ansiedad, estrés. Algunos autores relacionan estas enfermedades con la creciente soledad del individuo ante el desgarramiento del tejido social y solidarió. En cuanto al SIDA, se han hecho grandes progresos en los países ricos donde, desde 1997, ha empezado a retroceder en un 27 por ciento, pero en los países pobres no se detiene la progresión. De los 14 millones de seres humanos que desde 1980 han muerto infectados por el SIDA, el 95 por ciento pertenece a países pobres. De los 34 millones de enfermos de SIDA, 22 millones son habitantes de África austral, donde sólo en 1998, 5800000 personas contrajeron el virus.

Una de las grandes expectativas en el terreno de la salud es la investigación del genoma humano $^{7}$. Cuatro mil enfermedades podrían tener como causa malformaciones genéticas. Nos hallamos en el umbral de descifrar los 100000 genes de nues-

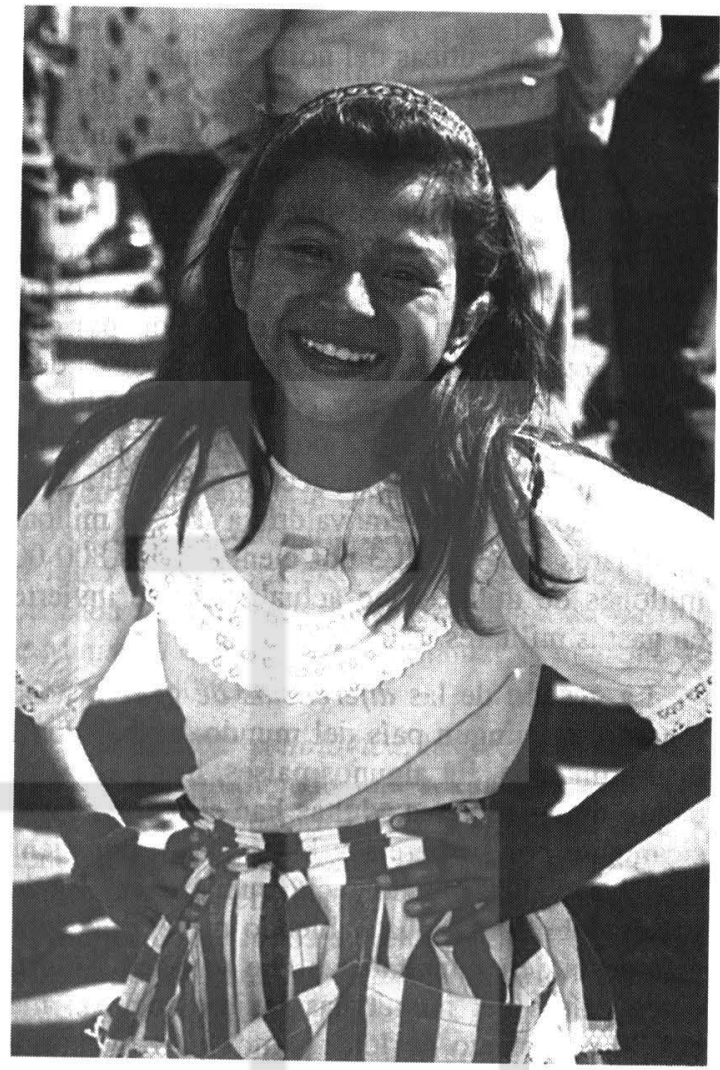

tro ADN. Hasta ahora se ha descifrado el 7 por ciento del genoma humano: 4000 genes. El problema es que las grandes industrias farmacéuticas patentan sus investigaciones sobre el genoma humano, pues la información genética sobre determinadas enfermedades ofrece la posibilidad de fabulosas ganancias. Actualmente hay seis veces más información en bancos de datos privados sobre el genoma humano (de acceso limitado y de pago) que de dominio público. Los intereses de las industrias farmacéuticas y su defensa por los países ricos genera un grave apartheid sanitario ${ }^{8}$. Las in-

6. A. Giddens, Modernidad e identidad del yo, Ed. Península, Madrid, 1998, p. 133-139.

7. Es urgente una legislación mundial al respecto para decidir hasta dónde es legítimo el uso de información genética para las investigaciones delictivas, para los seguros, el trabajo, para escoger el sexo de los hijos y otras cualidades, para manipular las células sexuales que pueden afectar a todas las generaciones futuras, para frenar las patentes y monopolios de las grandes compañías y propiedades.

8. En Tailandia, el medicamento para combatir un tipo especial de meningitis es fabricado por una empresa norteamericana a un precio de 400 dólares el frasco. Cuando los tailandeses fabricaron el mismo medicamento a un costo de 100 dólares por frasco, Estados Unidos los amenazó con imponer impuestos a sus principales productos de exportación y tuvieron que abandonar su producción. En África del Sur también sc logró producir medicamentos contra el SIDA a mitad de precio que en Estados Unidos. La firma americana Merell Dow desarrolló un medicamento contra la enfermedad del sueño, transmitida por la mosca tse-tse, que vendía a precio de oro. Como la mayoría de las $\mathbf{1 5 0} 000$ personas que mueren cada año por la enfermedad en África no podían pagarlo, 
dustrias farmacéuticas del norte intentan evitar -a través de la OMC - toda excepción a los derechos de las patentes, mientras acceden gratuitamente a la materia prima del sur para producir medicamentos que luego son inaccesibles para estos mismos países. En África, el 72 por ciento de la riqueza medicinal de las plantas es explotada por companías extranjeras; en Colombia, el 84 por por ciento; en Ecuador, el 97 por ciento. Los países desarrollados, con el 14.6 por ciento de la población mundial, consumen el 82 por ciento de los medicamentos. El costo para un acceso universal a servicios básicos de salud equivaldría a 25000 millonęs de dólares anuales. El 3 por ciento de los 800000 millones de dólares que actualmente se invierten en gastos militares.

La gestión de las diferencias de género no ha logrado, en ningún país del mundo, acabar con la discriminación. En algunos países, hasta el 50 por ciento de las mujeres adultas han sido forzadas físicamente por su pareja y hasta un 70 por ciento confiesa ocultar la violencia que padece. En los países pobres continúa habiendo un 60 por ciento más de mujeres analfabetas que varones. Sólo en cinco países del mundo las mujeres ocupan más del 30 por ciento de los asientos parlamentarios. En 31 países ocupan menos del 5 por ciento. Las mujeres emplean dos tercios de su tiempo de trabajo en actividades no remuneradas, mientras que los hombres tan sólo un cuarto. El aumento del divorcio en los países ricos se tiende a relacionar con una menor discriminación de la mujer en los países ricos. En Dinamárca y Suecia cerca del 50 por ciento de los niños nacen fuera del matrimonio. En muchos países sólo una minoría de niños crece en un entorno "tradicional", donde el padre y la madre están casados y viven en su misma casa.

En la gestión cultural resalta que el analfabetismo en el mundo ha descendido del 52 por ciento, en 1970 , al 28 por ciento, en 1997; aunque en países como Estados Unidos, el analfabetismo funcional (incapaces de leer las instrucciones de un frasco de medicina o un cuento a un niño) es del 20 por ciento. El fin de la guerra fría ha supuesto una expansión importante de grupos religiosos en todo el mundo, especialmente en los países de la ex Unión Soviética. Se calcula que 2000 millones de personas se consideran más o menos cristianas, 1200 millones islámicos, 900 hinduístas, $900 \mathrm{mi}$ Ilones no creyentes (agnósticos o ateos), $350 \mathrm{mi}$ llones budistas y 190 millones adscritos a diferentes religiones animistas. También sorprende el espectacular abaratamiento y aumento de la comunicación mundial: El costo de una llamada telefónica de tres minutos de Nueva York a Londres costaba 245 dólares en 1930, 50 dólares en 1960, 3 dólares en 1990 y 35 centavos de dólar en 1999. Esta facilidad comunicativa contrasta con el monopolio de la información y la concentración de los productos culturales del norte: Las agencias de los países ricos manejan 37'5 millones de palabras diarias frente a $0^{\prime} 3$ millones de las agencias del sur, donde vive la mayoría de la población mundial. Aunque la India es la nación que realiza más películas, Hollywood llega literalmente a todas las naciones del mundo. El 50 por ciento de las películas que se ven ahora en el mundo son producidas en Estados Unidos, frente al 30 por ciento que representaba en 1980. Estados Unidos domina el 70 por ciento del mercado en Europa, frente al 56 por ciento en 1987, el 83 por ciento en Latinoamérica y el 50 por ciento en Japón.

Internet, el instrumento de comunicaciones más rápido que ha existido, abre grandes posibilidades culturales para la población mundial, pero también para el crimen y la especulación. La transmisión de datos a la velocidad de la luz hace muy difícil para los estados controlar el movimiento de la red. Diferentes políticas sobre los programas de cifrado y la privacidad de la red se discuten en Europa y Estados Unidos. La red contaba con 140 millones de usuarios, en 1998, y se pronostica que habrá más de 700 en el 2001 . Internet y la prensa han tenido un papel protagónico en muchas denuncias de corrupción. Los gobiernos viven en un entorno informativo y lo que antes políticamente dependía sólo de prebendas y de acuerdos entre bastidores sale a la luz más fácilmente. Entre 1994 y 1996, 63 periodistas rusos fueron asesinados por las nuevas mafias. En 1998 fueron encarcelados por ejercer su profesión cien profesionales. Siria y

se abandonó la fabricación del medicamento. Gracias a la presión de Médicos sin fronteras, la empresa acaba de transmitir los derechos de comercialización a la Organización Mundial de la Salud. 
Turquía rivalizan por el mayor número de periodistas torturados durante su detención, aunque las amenazas y agresiones afectaron a casi 700 periodistas en todo el mundo".

Diversos sociólogos subrayan el aumento de la reflexividad, la destradicionalización, la desnaturalización y la emergencia de un nuevo individualismo global. Los autores socialdemócratas suelen ver en el individualismo un egoísmo favorecido por el mercado y el rechazo de la solidaridad estatal. Los neoliberales suelen ver en él la decadencia moral favorecida por la permisividad de los sesenta. Según A. Giddens, el individualismo está asociado a la difuminación de la tradición y de la costumbre en nuestras vidas. El individualismo no sería ante todo fruto de una especie de egoísmo natural, sino del aumento de la reflexividad en nuestras vidas (las opciones sexuales, de formas de convivencia, de pareja, de estilo de vida, de cultura, de alimentación, etc. son tomadas por los individuos más activamente que en las generaciones anteriores) que hace que la cohesión social no pueda garantizarse ni mediante la acción vertical ni mediante el apego a la tradición. El nuevo individualismo estaría ligado a una vida más abierta y a una identidad más reflexiva que en las generaciones anteriores ${ }^{10}$. En cualquier caso, hay una notable coincidencia en atribuir el aumento de las expresiones fundamentalistas en los países pobres y de la xenofobia, el racismo y el nacionalismo excluyente en los países ricos a la crisis del Estado-nación y a la imposición de un mercado mundial.

Junto a este tipo de movimientos emerge también una sociedad civil mundial. A principios de siglo había 20 organizaciones gubemamentales intemacionales y 180 organizaciones no gubemamentales transnacionales. Hoy hay más de 300 de las primeras y 5000 de las últimas. A menudo se desarrolla en ellas una cierta conciencia cosmopolita de que no hay alteridades radicales ni personas que no tengan nada que ver con nosotros. También empieza a haber capacidad para movilizarse mundialmente: La compañía de petróleo Shell planeó, en 1995, deshacerse de una plataforma petrolífera; las protestas mundiales y el boicot a la gasolina promovido por entidades ecológicas hicieron cam- biar a Shell. Una pléyade de organismos no gubernamentales, en connivencia con gobiernos del sur, impidieron que en la última reunión de la $\mathrm{OMC}$, en Seattle, se realizaran acuerdos antidemocráticos". Para las clases medias y altas mundiales, vivir en un país no significa vivir necesariamente con los demás, y vivir con los demás no significa vivir en un único lugar. Pueden globalizar su biografia: tener su familia en Estados Unidos o en Europa, trabajar parte del año en un organismo no gubernamental en El Salvador y otra parte del año en África o en la India, y platicar cada día con su novia por Internet. El mundo, las distancias y el tiempo se les hacen pequeños. En cambio, para los excluidos su biografía se concentra cada vez más en un único lugar y las distancias espaciales y temporales son cada vez más enormes. Hay niños en barrios de Managua que no han visto jamás el mar que se encuentra a $80 \mathrm{Km}$.

En la gestión tecnológica, las técnicas anticonceptivas han propiciado una sexualidad cada vez más ligada al erotismo y a la relación afectiva y menos a la reproducción. Las nuevas tecnologías reproductivas (Fertilización in vitro, ectogénesis - producción de niños sin embarazo-, clonación -individuos genéticamente idénticos-) y la ingeniería genética son técnicas que pueden afectar el futuro de la humanidad entera, aunque se desarrollen en un solo país. Con todos sus riesgos y peligros, algunas tecnologías ofrecen un gran potencial para el avance de la humanidad y para la erradicación de la pobreza, pero no con unos derechos de propiedad intelectual cada vez más estrictos. Los derechos de propiedad aumentan el precio de la transferencia tecnológica a los países pobres, facilitan el monopolio a las multinacionales, y dificultan el control democrático de las tecnologías.

La gestión de la violencia muestra que desde el final de la segunda guerra mundial han fallecido 50 millones de personas en conflictos armados - la mayoría población civil- y que el tráfico ilegal de drogas supone un 8 por ciento del comercio mundial, superior al comercio de vehículos de motor o de hierro y acero y a los ingresos del crimen organizado. Se calcula que hay unos 200 millones de adictos en el mundo. Se estima que en 1995, el

9. Informe sobre la "Libertad de Prensa en el Mundo", presentado en 1999 por la Asociación Internacional Reporteros Sin Fronteras (RSF).

10. A. Giddens, La transformación de la intimidad, Ed. Cátedra, Madrid, 1998.

11. Agnes Sinai, "le jour où le Sud se rebiffa", Le Monde diplomatique, Janvier, 2000 , p. 4. 
tráfico ilegal de droga alcanzó los 400 mil millones de dólares. El comercio ilegal de armas ha aumentado. Se atribuye a este tráfico el gran aumento de asesinatos (cinco veces) en la última década. En Europa del este, cada año 500000 mujeres y niñas se prostituyen ${ }^{12}$. Las mafias mundiales desamollan actualmente alianzas y estrategias globales. La reconversión y privatización de los ejércitos de la guerra fría (por ejemplo, el ejército rojo pasó de cuatro millones a 1 millón de soldados de 1991 a 1995) han constituido un magnífico caldo de cultivo para diferentes organizaciones criminales. En América Latina, el fin de la guerra fría no ha supuesto una reducción de las muertes violentas. Desde México a Argentina se producen 140000 homicidios al año y veinticuatro asaltos callejeros por minuto. En Colombia, el país más violento del mundo, seguido muy de cerca por El Salvador, se producen 77.4 víctimas anuales por cada 100000 habitantes. En Estados Unidos, la proporción es de 4 víctimas por cada 100000 habitantes, y en China y la UE se producen 1.4 víctimas por cada 100000 habitantes. El que la ley continúe sujeta a los estados nación permite que crímenes reales no consten como tales. Por ejemplo, si un francés vende en Holanda, a través de Internet, acciones falsas a un alemán y la operación es controlada por un inglés que reside en Mónaco y cuyas cuentas bancarias están en Panamá, ¿en qué jurisdicción se persigue el delito?

Un problema muy grave que enfrenta la persecución del crimen es el adelgazamiento de la diferencia entre el crimen y el negocio. El redactor económico de la revista Facts, de Zurich, puso a prueba las convicciones éticas de diez de los más prestigiosos bufetes de abogados de Suiza. Cuenta que una empresa rusa debe vender osmio (materia altamente tóxica) a una empresa checa, sin que las autoridades rusas se enteren. Nueve de los diez bufetes contestaron positivamente al falso traficante. La mayoría de ellos propusieron la creación de una sociedad en las islas Caimán, en Linchestein o en Panamá como medio para esconder la operación ${ }^{13}$. Del mismo modo es habitual que el cajero de un banco que estafa sea denunciado a la policía, pero si es un jefe de división, es discretamente despedido, y si es de la alta dirección, se negocia su silencio.

En la gestión ecológica, el uso de recursos materiales se ha reducido de manera considerable en los últimos años, y los temores muy publicitados de que el mundo agotaría recursos no renovables, como el petróleo y los minerales, han resultado falsos. El consumo ha cambiado en favor de productos y servicios con menor densidad de materiales. Este proceso de desmaterialización hace que los recursos no renovables no constituyan hoy un problema tan urgente. Sin embargo, ello significa también el fin de algunas ventajas comparativas que podrían tener los países pobres al poseer mayor cantidad de recursos naturales y materias primas que los países ricos. En cambio, el deterioro de los recursos renovables aumenta de una manera alarmante. Desde 1970, la superficie forestal por cada mil habitantes se ha reducido de 11,4 kilómetros cuadrados a 7,3. En los últimos dos decenios, América Latina y el Caribe perdieron siete millones de hectáreas de bosques tropicales, y Asia y África -al sur del Sahara - cuatro millones de hectáreas cada uno. La mayor parte de las pérdidas se han producido para satisfacer la demanda de madera y papel que se ha duplicado y quintuplicado, respectivamente, desde 1950. Pero más de la mitad de la madera y casi tres cuartas partes del papel se usan en los países industrializados.

Las emisiones anuales de bióxido de carbono (CO2) se cuadruplicaron en los últimos cincuenta años. Uno de los efectos más perniciosos de la contaminación sería el recalentamiento mundial de la atmósfera, que amenaza con arruinar las cosechas, inundar permanentemente grandes superficies y aumentar la frecuencia de las tormentas y las sequías. La temperatura media superficial de la Tierra, en 1998 , ha sido la más alta desde que se comenzó a medir la misma a mediados del siglo pasado. Algunos científicos consideran que la ferocidad de los últimos huracanes en el Caribe (el "Mitch" provocó 9000 muertos; las lluvias y el deslave de las tierras, fruto de la erosión, más de 30000 muertos en Venezuela) se debe al aumento de la temperatura terrestre. En cualquier caso, los más perjudicados por la gestión ecológica son los más po-

\footnotetext{
12. En Berlín se calcula que una mujer emigrante ilegal explotada sexualmente genera una media de 350 dólares. De esta suma recibe sólo 20 . En Bélgica se ofrece residencia permanente a las mujeres explotadas sexualmente que deciden cooperar con la justicia.

13. Ibid., pp. 43-44.
} 
bres de la población mundial, aquellos que destruyen y contaminan menos. La quinta parte de la población mundial, que vive en los países de ingreso más elevado, genera el 53 por ciento de las emisiones de bióxido de carbono y consume el 84 por ciento del papel mundial, y la quinta parte más pobre genera el 3 por ciento del bióxido. Brasil, China, India, Indonesia y México se hallan entre los países en desarrollo con las emisiones más elevadas. Pero con poblaciones enormes, sus emisiones per cápita siguen siendo minúsculas, 3,9 toneladas métricas por año en México y 2,7 en China, en comparación con 20,5 toneladas métricas en Estados Unidos y 10,2 en Alemania. La pobreza y el medio ambiente están atrapados en una espiral descendente. Los pobres se ven obligados a agotar los recursos para sobrevivir; esta degradación del medio ambiente los empobrece todavia más. Cuando esta espiral descendente que se refuerza a sí misma resulta extrema, los pobres se ven obligados a desplazarse, en número cada vez mayor, a tierras ecológicamente frágiles. Casi la mitad de los habitantes más pobres del mundo -más de 500 millones - viven en tierras marginales.

\section{2. ¿Es posible una gestión democrática de la so- ciedad mundial?}

Si ya es difícil poner orden en nuestra propia casa, poner orden en el planeta, después de unas estadísticas apabullantes como las anteriores, parece completamente fuera de nuestras posibilidades. Sin embargo, la cuestión no es ya si es posible gestionar políticamente el mundo, sino si en lugar de la ley del más fuerte que lo sigue rigiendo, un poco atemperada por sus disfraces y vestidos, podemos impulsar una gestión política con un mejor reparto del poder. Los mismos Estados Unidos parecen haber pasado de la promoción de las dictaduras en América Latina a la promoción de democracias de baja intensidad. Probablemente no es una reflexión ética lo que ha llevado a ese país a fortalecer la democracia en lugar de apoyar los golpes de Estado, sino el convencimiento de que las democracias nacional-liberales son un instrumento mucho más útil para difuminar las tensiones sociales, hacer negocio y contener a amplias capas pobres de la población susceptibles de opo-

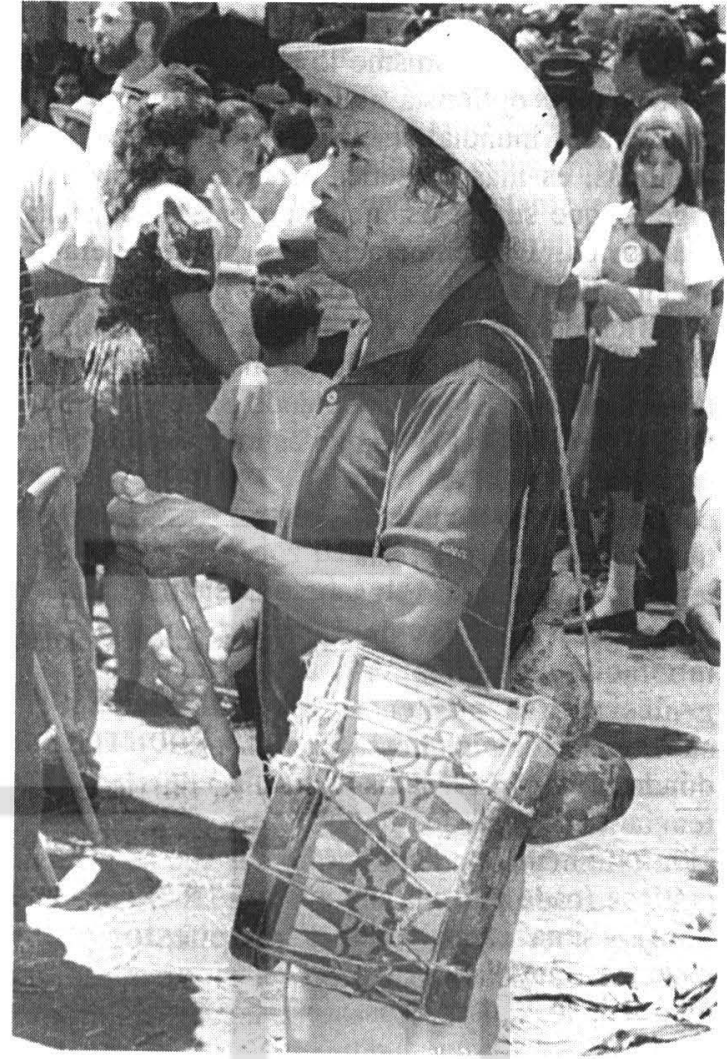

nerse al sistema. Ciertamente la democracia que hoy existe en el mundo es más bien una elitocracia, un sistema en el cual gobierna un pequeño grupo, y la participación de los ciudadanos en las mismas suele limitarse a seleccionar los dirigentes propuestos por élites competidoras, que a lo que Robert Dahl ha llamado una poliarquía: "gobierno de los muchos"14 . Aún así, creo que una democracia mundial de baja intensidad sería mejor para los países pobres que el autoritarismo imperante. Pero la exploración y la emergencia de una democracia mundial de baja intensidad o, mucho más idealmente, de una democracia poliárquica global no sólo está en pañales, sino que pocos serán aquellos trabajos teóricos que cuestionen que la nación-estado deba permanecer en el centro del pensamiento democrático.

Más de uno pueda ser que al leer esto frunza el ceño y piense que es totalmente imposible radica-

14. Robert A. Dahl, La democracia una guia para los ciudadanos, Santillana, Madrid, 1999, p. 105. La democracia poliárquica implicaría: (1) Cargos públicos electos, (2) Elecciones libres, imparciales y frecuentes, (3) Libertad de expresión, (4) Fuentes alternativas de información, (5) Autonomía de las asociaciones, (6) Derecho de ciudadanía para los residentes permanentes. Esta democracia poliárquica se distinguiría de la democracia popular (de parti- 
lizar y expandir la democracia más allá del marco de los estados-nación. No sé si le servirá de consuelo saber que yo mismo lo tengo fruncido y que no soy muy optimista al respecto. Creo que una democracia mundial, incluso en sus formas más anodinas, es más antitética al sistema económico vigente que su coexistencia con países socialistas totalitarios. La democracia que puede tolerar el sistema tiene sus límites. Lo más probable es que el déficit democrático y el absolutismo mundial se extiendan y que las decisiones más cruciales para la humanidad se sigan adoptando entre elites políticas y burocráticas, y lo que es mucho peor, elites económicas, fuera de todo control político democrático. Pero de seguir esta tendencia, la cuestión es hasta qué punto las democracias estatales vigentes podrán mantener su legitimidad y hasta dónde llegará la coexistencia entre estados-nación mínimamente democráticos (cada persona un voto) y una especie de dictadura mundial del capital y de los países ricos. temente a sus agricultores y Estados Unidos las exportaciones agrícolas, ambos exigen a los latinoamericanos que no subvencionen su sistema agrícola. En este sentido, es muy ilustrativa la paradoja que supone que los mismos que criticaban a la Unión Soviética y a Cuba por la falta de libertad de movimiento, hoy que tanto cubanos como soviéticos pueden salir de sus países se les impide la entrada libre a occidente. Tanto $M$. Tatcher, como R. Reagan, verdaderos adalides de este modelo político, trataron de compaginar esta liberalización del mercado en favor de los ricos con la defensa de las instituciones tradicionales propia de los conservadores: la nación, la familia, la enseñanza de la religión como código moral, la penalización de la droga y del aborto, el control de los programas de enseñanza, etc. Las alusiones xenófobas no son del todo extrañas en las proclamas de autores neoliberales y tampoco es raro que se conciba a las familias monoparentales u homosexuales como decadentes. Es

\section{La democracia nacional-liberal conservadora}

Este apartado podría titularse también la gestión política de la actual sociedad mundial. Aunque hoy es habitual hablar de "neoliberalismo" para describir la ideología y el modelo económicopolítico imperante, lo cierto es que propiamente el neoliberalismo analizado a escala global tiene muy poco de liberal. Es, más bien, un liberalismo allí donde el liberalismo beneficia a los países ricos (desmantelamiento de los estados en los países pobres, libre flujo de capital) y un proteccionismo allí donde el liberalismo beneficiaría a los países pobres (prohibición del libre tránsito de la mano de obra y de la libre circulación de los productos competitivos de los países pobres). Donde los dogmas liberales podrían beneficiar a los países pobres, no rige el mercado, sino las políticas más proteccionistas. Un ejemplo de ello lo tenemos en la agricultura, donde los países del sur podrían ser competitivos. Mientras Europa subvenciona fuer- por ello que una designación más propia para el neoliberalismo sería quizás la de nacional-liberalismo conservador o neoconservadurismo. Esta tensión entre conservadurismo moral y mercado genera una de lás principales contradicciones del neoliberalismo, pues nada hay más disolvente de la tradición que las fuerzas de mercado, a pesar de que los neoconservadores acusan de ello a la educación y al relajamiento de las costumbres.

Los neoliberales, tanto en Estados Unidos como en Europa, bajo aparentes organismos multilaterales, suelen buscar la intervención unilateral en el mundo y un poco de disimulo y de formalidades que vistan a políticas aislacionistas. Es decir, lo que se suele imponer en los foros internacionales vigentes son decisiones unilaterales a las que los países pobres, con la mayor parte de la población mundial, sólo pueden asentir o comentar un poco. En el nacional-liberalismo existente, el multilateralismo y la democracia de orga-

do único), de las democracias decimonónicas de sufragio restringido, y de las democracias asamblearias y participativas griegas y de comunidades pequeñas. 
nismos intemacionales es menor cuanto más poder y relevancia tienen en el mundo (piénsese en la OMC, el FMI, El BM, el Consejo de seguridad de la ONU etc.). A las instituciones más democráticas y que sirven más a los intereses de los países pobres se las tiende a estrangular financieramente, mientras se potencian las organizaciones económicas y financieras mundiales privadas o para-estatales regidas antidemocráticamente (Banco Mundial, Fondo Monetario Intemacional, Organización Mundial de Comercio), que son las que disponen de una capacidad de intervención efectiva en la gestión del mundo. Lo que el nacional-liberalismo está construyendo no es una economía mundializada, sino el archipiélago capitalista mundial en el cual algunas islas, grandes o pequeñas, concentran casi la totalidad de las capacidades científicas y tecnológicas y financieras, evitando toda regulación política mundial mínimamente democrática que pudiera impedir que sus intereses fueran cuestionados por la población y los ciudadanos de los países pobres.

\section{La democracia liberal-libertaria}

Los liberales libertarios, en contraste con los liberales "conservadores", suelen ser liberales también en cuestiones morales: apoyan la libertad sexual o la despenalización de la droga. Frente a la democracia doctrinaria (dictadura de las mayorías) buscan establecer una democracia legal o libertaria ${ }^{15}$ limitada siempre por las libertades individuales. Las mayorías tienen que respetar los principios individuales (autonomia individual, libertad de expresión, libre movimiento, etc.) que están por encima de las legislaciones, del Estado y de la actividad política. Los derechos de los individuos a su autonomía no son algo que pueda decidirse democráticamente. Los políticos no pueden inmiscuirse en el imperio de la ley que es la libertad y el respeto a los derechos individuales.

La democracia liberal-libertaria propone una sociedad mundial de mercado libre y una red de estados mínimos. La mejor política económica es la de la absoluta libertad, de manera que cada país se especialice en aquellas actividades para las que disponga de "ventajas comparativas". La adopción del libre comercio amortiguará por sí sola las diferencias mundiales, siempre que haya una libertad absoluta de factores de producción (mano de obra, capitales). Teóricamente, la rentabilidad del capital sería mayor en los países pobres al tener salarios mucho menores. Si no hay traba alguna para la libre circulación de capitales, estos emigrarán a los países del sur hasta que se instaure el equilibrio con el norte, tanto en la retribución del capital como en el nivel de los salarios. Lo único que se necesitaría es que los países receptores del capital generaran las condiciones adecuadas para acoger la inversión extranjera: infraestructura, formación, transparencia, justicia y flexibilidad absoluta para repatriar beneficios. De cumplirse las predicciones liberales, los países ricos exportarían productos sofisticados y en los países pobres se producirían materias poco elaboradas donde se requiere sobre todo de mano de obra. Pero eso no se cumple porque, de hecho, hay muchos liberales que son nacional-liberales: liberales por fuera y proteccionistas por dentro. La red de estados mínimos debe preservar sobre todo el imperio de la ley (derechos individuales) y ofrecer una red de seguridad para aquellos en que el mercado es una fuente ineficiente. Esta red estaría sujeta a una autoridad superior elegida democráticamente. Su cometido sería asegurar el imperio de la ley y de la libertad en el plano global. Para llegar a este orden liberal pacífico y global habría que ir caminando hacia asociaciones $y$ autoridades regionales.

Es importante destacar que, a diferencia del nacional-liberalismo, los liberales-libertarios critican el aislacionismo, el estado-nación y los mercados nacionales defendidos por conservadores, nacional-liberales y nacionalistas de izquierda. También sostienen que un mercado sin fronteras es muchísimo más eficiente y que la ineficiencia del mercado mundial global estriba precisamente en la persistencia de las restricciones fronterizas artificiales actuales. No se trata de que el liberalismo sea la solución a los problemas de la sociedad mundial, sino solamente de subrayar que probablemente el mal llamado "neoliberalismo" es más perjudicial para los países pobres que un liberalismo mundial ortodoxo. Una política liberalizadora podría ser más beneficiosa para los países pobres que el nacional-liberalismo imperante si, además del libre flujo de capitales, supusiera el libre flujo de mercancías y de mano de obra. Más beneficioso todavía para los países pobres sería un nacional-libera-

15. F.A., Hayek, Law, Legislation and Liberty, Londres, Roudlege/Kegan Paul, 1982. R. Dworkin, "Foundations of Liberal Equality", The Tanner Lectures on Human Values, Vol. XI, Salt Lake City, Universidad de Utah. 
lismo al revés. Es decir, una liberalización allí donde ésta beneficiara a los países pobres y un proteccionismo allí donde éste perjudicara a los ricos. Ciertamente este planteamiento ha sido y es objeto de muchas críticas: en nombre de la libertad se esconden las estructuras reales de poder; la autonomía y la libertad están más amenazadas por la desigualdad que por la coerción de los gobiernos; la incongruencia de este orden liberal ideal con el sistema de corporaciones multinacionales y las estructuras oligopólicas, etc.; pero no creo que sea del todo adecuado poner en el mismo saco a nacional-liberales conservadores y a liberales libertarios.

\section{La democracia de la nueva socialdemocracia o "tercera vía"}

Quizás sea interesante empezar este apartado por el planteamiento de un "converso". De alguien como G. Soros que ha escrito un libro sobre la crisis del capitalismo mundial, muy poco tiempo después de haber alabado ampliamente ese mismo liberalismo mundial y de haberse hecho muy rico aprovechándose del amplio espacio transnacional que queda fuera de todo control político democrático ${ }^{16}$. G. Soros se adscribe a la influencia del pensamiento filosófico de Popper y recoge de él, en particular, la noción de sociedad abierta. Sin embargo, en el ámbito económico se aparta substancialmente de la doctrina convencional, critica duramente la inoperancia conceptual e interpretativa de la economía liberal y utiliza conceptos propios de la tradición marxista como sistema capitalista mundial, centro-periferia y fundamentalismo de mercado. G. Soros llega a afirmar incluso que "Marx y Engels hicieron un análisis muy bueno del sistema capitalista hace 150 años, mejor en algunos aspectos, debo decirlo, que la teoría del equilibrio de la economía clásica"17.

G. Soros critica la fe en el mercado y considera que las actuales tendencias ponen precisamente al capitalismo al borde del abismo: "Sostengo que la situación actual es poco sólida e insostenible. Los mercados financieros son intrínsecamente inestables y existen necesidades sociales que no pueden satisfacerse dando carta blanca a las fuerzas del mercado. Lamentablemente, no se reconocen estos defectos. Existe, en cambio, el convencimiento general de que los mercados se autocorrigen y que una economía global puede prosperar sin necesidad de una sociedad global. Se afirma que la mejor manera de servir el interés común es permitir que cada cual defienda sus propios intereses y que los intentos de proteger el interés común mediante la toma de decisiones colectivas distorsiona el mecanismo del mercado [...] Este fundamentalismo del mercado es el responsable de que el sistema capitalista global carezca de solidez y sea insostenible"18. Ante el declive del estado-nación considera que deben fomentarse el derecho, las instituciones intemacionales y algún sistema global de toma de decisiones, y aconseja que el grupo de países aliados en tomo a Estados Unidos y la OTAN lideren la creación de una sociedad abierla global. Es muy posible que su cambio doctrinal se deba a que ahora aprecia que el riesgo de las tormentas financieras y monetarias hacen peligrar los intereses del capital financiero mismo, pero más allá de sus motivaciones nos interesa destacar la cercanía de los planteamientos de G. Soros con los de algunos socialdemócratas menos advenedizos, como Tony Blair, L. Jospin, Gorvachov, Felipe González, Raúl Alfonsín y otros líderes conocidos de la socialdemocracia, cuyos planteamientos podemos encontrar en el foro socialista para el progreso global.

En general, la socialdemocracia ha evolucionado desde una percepción estatalista a una concepción global. J. K. Galbraith, reconocido socialdemócrata asesor de Kennedy, en su colaboración al informe sobre desarrollo humano de $1998^{14}$ reconoce el error de sus anteriores publicaciones al no

16. George Soros, húngaro de nacimiento y en la actualidad ciudadano de Estados Unidos, es el prototipo del magnate de los mercados financieros. Su más famosa intervención se produjo en el mercado internacional de divisas cuando con su presión logró expulsar a la libra esterlina y a la lira del sistema monctario europeo y casi lo logró también con el franco francés y la pescta. Se le atribuyen acciones semejantes en otras latiludes e incluso el Gobierno de Malasia le ha acusado - al parecer injustamente- de ser el promotor de la crisis de ese país e incluso de la reciente crisis asiática de 1997 y 1998.

17. G. Soros, La crisis del capitalismo global, Editorial Debate, Madrid, 1999, p. 136.

18. Ibid, p. 158 y ss.

19. J. K. Galbraith, Informe sobre el desarrollo humano, 1998, p. 42. 
haber destacado suficientemente la globalidad de la economía. Los dos problemas más graves del mundo actual serían la concepción de que la diferencia entre el mundo opulento y el mundo poscolonial es algo natural y el ídolo de la soberanía del estado que sigue intocable. A quienes les ha tocado vivir en países ricos o en segmentos ricos de los países pobres, disfrutan de su bienestar sin ninguna sensación inquietante de responsabilidad, como si en realidad merecieran su opulencia y como si ésta no tuviera que ver absolutamente nada con la miseria de las mayorías de la humanidad. Respecto a la soberanía, considera que nada hay en este momento en el mundo que sirva tanto para proteger el desorden, la pobreza, la penuria y el festín de los ricos. Para J. K. Galbraith, no se trata de que Estados Unidos u otros países aliados, como suele suceder en las intervenciones humanitarias actuales, estén por encima de las soberanías nacionales, sino de articular un poder mundial independiente y democrático que pueda combatir la comupción, el desorden y la crueldad de los malos gobiemos.

\section{El planteamiento so-} cialdemócrata teórico más poderoso y más susceptible de influir las políticas socialdemócratas en el futuro inmediato lo constituye probablemente el trabajo de A. Giddens ${ }^{20}$. La pretensión de $\mathrm{A}$. Giddens de renovar la socialdemocracia es lo que se ha bautizado como tercera vía ${ }^{21}$. Sus críticos suelen ver en esta propuesta una especie de neoliberalismo recalentado. Se podría resumir en cinco grandes ejes: la conciencia de la mundialización y de la búsqueda de un nuevo papel para el estado-nación dentro de un mundo cosmopolita frente a la concepción estatista y desarrollista de la vieja socialdemocracia; la importancia de la autonomía individual y de la promoción de una sociedad civil activa frente al colectivismo y la burocracia tradicional; la promo- ción de políticas de elección y de asunción de riesgos y responsabilidades frente a políticas paternalistas; la promoción de políticas de bienestar positivo para toda la población (impulso de la educación durante toda la vida, salario mínimo para todos, estímulo de la actividad cívica, vinculación de las empresas privadas, dar iniciativas a las personas etc.,) frente al subsidio de los más pobres; y una nueva relación con la naturaleza desde una sensibilidad ecológica y la asunción del riesgo.

Los socialdemócratas latinoamericanos experimentan la necesidad de políticas sociales mucho más dramáticamente que sus colegas del norte, pues es precisamente en muchos países de Latinoamérica que las recetas neoliberales son llevadas a una exageración casi absoluta. Lo vemos en Centroamérica. Los gobiernos nacionales compiten para ofrecer las menores cargas sociales posibles para atraer capital. El drama que experimenta la socialdemocracia latinoamericana es que si regula el mercado, los inversores se van a otro lado y desestabilizan al estado inmediatamente. Pero si no se regula, se excluye a gran parte de la población de una vida mínimamente digna y la democracia se convierte en una trampa. Entre algunos socialdemócratas latinoamericanos goza de un cierto predicamento la idea de desconexión parcial del sur. Para satisfacer las necesidades prioritarias de los pueblos pobres, se trataría de realizar un despegue económico -fundamentalmente industrial - tomando medidas proteccionistas contra el mercado mundial y los países del norte, en particular. La aplastante mayoría de las naciones modernas, en un momento clave de su historia, aplicaron medidas proteccionistas fuertes para preparar o acelerar su despegue económico. Se trataría de organizar una coexistencia entre zonas diferenciadas, introdu-

20. Véase, por ejemplo, "Después del neoliberalismo: un nuevo camino", documento elaborado por un grupo de políticos e intelectuales latinoamericanos convocados por J. Castañeda en Nexos, México, 1998, muy influido por la propuesta "Tercera vía", de A. Giddens.

21. A. Giddens, La tercera vía, la renovación de la democracia, Ed. Taurus, 1999, Madrid. 
ciendo una suerte de proteccionismo como herramienta de planificación de las diferentes áreas de la economía mundial.

En general, para los socialdemócratas se trata de promover una mayor gobernabilidad mundial. Una estructura de gobiemo - local, nacional, regional y mundial - más fuerte significa un marco de reglas, instituciones y prácticas establecidas que disponen límites y ofrecen incentivos para el comportamiento de los individuos, las organizaciones y las empresas. Se trataría de una gobernabilidad global que discutiría la actual, determinada por el crecimiento económico y la estabilidad financiera, el absolutismo, la no-representatividad, la falta de instituciones de la sociedad civil y de mecanismos coercitivos para obligar a gobiernos y a corporaciones a respetar a la humanidad ${ }^{22}$.

Con todos los problemas de esta vía creo que el "keynesianismo global", recomendado por el PNUD, podria abrir un camino de esperanza para la humanidad. Eso sí, siempre queda pendiente el problema de fondo de saber hasta qué punto puede dar respuesta al reto de la amenaza medioambiental u ecológica un sistema económico que está obligado a crecer permanentemente. $i$ Es posible, realmente, un mundo donde todos crezcan un poquito y algunos muchísimo más, o el sistema capitalista mundial, aún atemperado keynesianamente, entranaría intrínsecamente la polarización económica de la sociedad mundial? Así, por un lado es cierto que algo de lo que se llama desarrollo nacional siempre es posible pero, ¿es posible un desarrollo mundial global? ¿Daría de sí el sistema capitalista mundial para construir una especie de Unión Europea mundial que subsidie a los más pobres? Ciertamente, si el sistema capitalista no entraña intrínsecamente que cualquier "desarrollo" de una parte del mundo es, en realidad, el reverso de una "declinación" o "subdesarrollo" de alguna otra parte, y si por algún milagro fuera posible que todos nos "desarrolláramos" simultáneamente o que al menos toda la humanidad se desarrollara un poquito, aun- que algunos se "desarrollaran" muchísimo más, sería posible llegar a la "paz perpetua" con un capitalismo debidamente reformado y controlado democráticamente por la humanidad, pero esto es justamente lo que cuestionan los socialistas.

\section{La democracia socialista}

El totalitarismo del socialismo real hace difícil hoy hablar de democracia comunista. Pero, de hecho, cuando Marx hablaba de dictadura del proletariado, no entendía por ella una tiranía, sino el dominio de una mayoría en una democracia real y no simulada como la burguesa. Marx se inspiraba en la Comuna de París, de 1871, con elecciones directas de todos los funcionarios y, probablemente, se habría tirado de los pelos de la barba al ver cómo la dictadura del proletariado se transformó en la dictadura de una vanguardia y, al final, de un sólo hombre. Sin embargo, el socialismo no sólo no se opone a la democracia, sino que una democracia de mediana intensidad parece requerir algún tipo de equidad y paridad social entre los seres humanos.

En este apartado agrupo a una serie de teóricos que, aunque pueden coincidir y transitar con la socialdemocracia y no posean alternativas claras al capitalismo, consideran que hay una serie de problemas, como el crecimiento indefinido y la degradación ecológica, que son intrínsecos y esenciales al sistema mismo. A diferencia de los socialdemócratas, todos coinciden en afirmar el colapso del sistema en las próximas décadas y en ver la crisis global del sistema como una ocasión de transformación del sistema económico mundial. En consecuencia, consideran que cualquier vía transitable para la humanidad debe implicar la exploración, la experimentación y la búsqueda de alternativas al sistema sin volver al extinguido paradigma leninista de una economía dirigida, planificada y centralizada por una vanguardia. Entre el capitalismo y la economía planificada y centralizada consideran que hay un margen por explorar.

22. En síntesis, la propuesta socialdemócrata global la encontramos esbozada en el último informe sobre el desarrollo humano (1999): aumento de impuestos, introducción del impuesto Tobin, introducción de un impuesto por envío de información vía Internet, reducción de la volatilidad financiera, salvaguarda de los derechos de los trabajadores de empresas transnacionales, establecimiento de un grupo de científicos independientes para propiciar propuestas tecnológicas que beneficien a la humanidad, condonación de la deuda externa de los países pobres, creación de un tribunal criminal internacional, democratización de las instituciones internacionales que controlan el grupo de los G-7, mayor poder para la asamblea general de la ONU e introducción de una nueva cámara con representación de la sociedad civil mundial. 
En este sentido, 1. Wallerstein plantea que la primera mitad del siglo XXI será más dificultosa, más perturbadora y, sin embargo, más abierta que todo lo que hemos conocido durante el siglo $\mathrm{XX}^{23}$. El moderno sistema-mundo, como sistema histórico, habría entrado en una crisis terminal y no sabemos si el sistema (o los sistemas) resultante será mejor o peor que el actual, pero sí sabemos que el período de transición será una terrible etapa llena de turbulencias. Lo más novedoso de las tesis de Wallerstein consiste en la afirmación de que, contra todas las apariencias, el colapso de los comunismos en 1989 no marcó un gran triunfo del liberalismo, sino más bien el colapso definitivo del liberalismo en tanto que geocultura definidora de nuestro sistema-mundo. El liberalismo prometió que las reformas graduales mejorarían las desigualdades del sistema-mundo y reducirían su aguda polarización. La ilusión de que esto era posible dentro de la estructura del moderno sistema-mundo habría sido un gran factor de estabilización, pues legitimaba los Estados ante los ojos de sus poblaciones a las que prometía un futuro mejor. El desencanto de la población mundial acabará, más temprano que tarde, con su tolerancia a la continua y creciente polarización del sistema-mundo. I. Wallerstein prevé que se producirán considerables tumultos, del mismo tipo que los ocurridos durante los años noventa, extendiéndose desde las Bosnias y Ruandas de este mundo hacia las regiones más ricas y consideradas más estables del planeta, como Estados Unidos. El caos provendría básicamente por la incapacidad del sistema de desarrollar nuevas formas de organización social y política más allá del Estado-nación y por su relación excluyente con la periferia africana y con

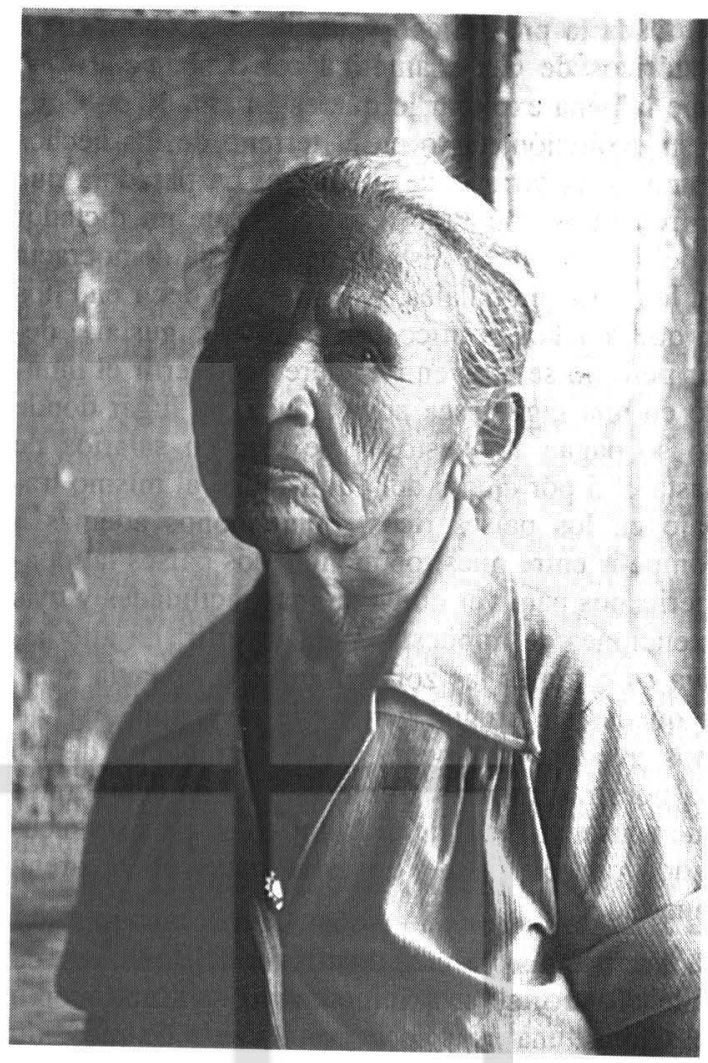

partes de Asia y América Latina. I. Wallerstein, al igual que S. Amin ${ }^{24}$, N. Chomsky H. Dieterich ${ }^{25}$ y P. Bourdieu ${ }^{26}$, propone la construcción de un sistema político que reemplace al Estado-nación y se constituya en una unidad política en condiciones de gestionar un mercado ampliado, y considera que, en el mejor de los casos, podríamos avanzar hacia la constitución de un solo estado mundial.

23. I. Wallerstein, Después del liberalismo, Siglo XXI, Madrid, 1996.

24. En su último libro, S. Amin efectúa un conjunto de planteamientos sobre la situación actual del capitalismo, donde desmiente sus anteriores planteamientos sobre "la desconexión" del sistema como vía interesante para los países pobres. S. Amin señala la existencia de cinco monopolios que mantienen a la periferia subyugada al centro: El monopolio de la tecnología, el de los mercados financieros mundiales, el de los recursos naturales del planeta, el de los medios de comunicación y el de las armas de destrucción masiva. Con el fin de combatir los cinco monopolios, sugiere la reorganización del sistema mundial a partir de grandes regiones, que agruparían zonas dispersas de la periferia. De esta forma se podrían constituir la región latinoamericana, árabe, africana, del sudeste asiático, junto a China e India. A estas regiones cabe añadir Europa y la antigua Unión Soviética y, por supuesto, Estados Unidos y Japón. Cf. S. Amin, El capitalismo en la era de la globalización, Paidós, Barcelona, 1999.

25. Ambos autores consideran que ya existe una especie de protoestado mundial regido por el Grupo de los 7 (Estados Unidos, Alemania, Japón, Inglaterra, Italia, Francia y Canadá). EI BM y el FMI organismos ejecutivos del capital. El brazo político sería la ONU, con una estructura formal-democrática pero sin importancia práctica. Cf. N. Chomsky y H. Dieterich, La aldea global, Ed. Txalaparta, 1997.

26. P. Bourdieu, Contrafocs, Reflexions útils per resistir a la invasión neoliberal, Edicions 62, 1999, p. 137. 
Dada la proximidad y los lazos geopolíticos e históricos de Centroamérica con Cuba, creo que vale la pena explorar lo que está pasando en Cuba y su evolución, tanto en el terreno de los hechos como en el terreno de las ideas. La paradoja que enfrentamos con Fidel Castro es que un dictador en el interior de su Estado defiende la democracia en los foros mundiales, y se atreve a decir en ellos lo que muchos políticos piensan y les gustaría decir pero no se atreven: "Quieren convertir el mundo en una gigantesca zona franca, un lugar donde no se pagan impuestos y se ofrecen salarios de hasta el 5 por ciento del equivalente al mismo trabajo en los países ricos, poniéndonos además a competir entre nuestros menguados países latinoamericanos para ver quién da más facilidades y más exenciones de impuestos para invertir. La alternativa es o tomas las zonas francas o, todavía peor, te quedas sin ningún género de inversión. Así vamos quedando convertidos en extranjeros dentro de nuestras propias fronteras"27. Los demócratas que acusan a Fidel de dictador en su país son acusados por él mismo de estalinistas en la arena mundial.

Por detrás de los discursos altisonantes de Fidel Castro, se está imponiendo en Cuba, como en China, una especie de socialismo de mercado con autoritarismo político. Independientemente de las políticas norteamericanas particulares ${ }^{28}$, Cuba no parece tener otra alternativa que insertarse en la economía capitalista global, según los términos dictados por los instrumentos políticos y económicos transnacionales. El final de las repúblicas socialistas, con las cuales comerciaba Cuba y obtenía importantes subsidios, supuso que muchos auguraran el fin del régimen, pero, sorprendentemente, Cuba ha logrado - en un período relativamente corto y con todas las ambivalencias que se quiera- adaptarse a la nueva coyuntura mundial con menos sufrimiento, al menos para importantes capas de su población, que en la Unión Soviética y otras repúblicas ex socialistas. Impresiona sobre todo viniendo de Centroamérica la dignidad cubana. El PIB de Cuba es sólo un poco más alto que el de El Salvador, pero está mucho mejor repartido y no hay barrios de miseria, niños pidiendo en la calle, ni indigencia. Las calles son seguras, puede pasearse tranquilamente a las dos de la madrugada por la Habana y por los repartos, aunque se nota un aumento de la prostitución y una mayor tolerancia policial (previo pago en muchos casos) de la misma para favorecer el turismo sexual.

El repunte de la economía cubana es notorio. Después de 1995, cuando el dólar se cotizaba en 150 pesos, hoy la paridad vuelve a ser de 20 pesos. El 66 por ciento de las propiedades agrícolas son cooperativas. Existen 200000 trabajos individuales reconocidos por el régimen (artesanos, mecánicos, taxistas...). Los ciudadanos pueden ofrecer algunos servicios, como reparación de televisores, bicicletas, paladares (4 mesas), pero no pueden aunarse para establecer empresas. De ese modo, miles de técnicos y profesionales hacen ver que trabajan para el Estado para ganarse la vida vendiendo carteras, pavos, transportando turistas o realizando otros trabajos semiclandestinos. Los cubano-americanos y todos los extranjeros pueden pasearse en dólares por la isla e incluso invertir en empresas del Estado, cosa que les está vedado a los cubanos isleños. El dólar es prácticamente la moneda nacional. Las remesas de los familiares emigrantes benefician a una buena parte de la población, generando una creciente diferencia entre los que tienen familiares en el extranjero y los que no. Los salarios de un cubano son equivalentes a 20 dólares mensuales, pero con el subsidio de la casa, el gas, el transporte, el teléfono, los materiales escolares, la salud, parte de la comida y la escuela. No es de extrañar que la ineficiencia en el trabajo sea muy extendida. Para combatirla, el Estado ha introducido las primas en dólares en las empresas del Estado, pero no puede luchar contra la economía sumergida. El responsable de las reformas económicas del régimen actual parece ser Carlos Lage $^{29}$. Se apunta hacia una especie de economía mixta con un peso predeterminante del Estado y una participación, cada vez mayor, de cooperativas agrícolas y de la propiedad privada.

27. Fidel Castro, "Una revolución sólo puede ser hija de la cultura y de las ideas", febrero, Cuba socialista, 1999.

28. Se ha dicho, creo que con mucha razón, que la política de Estados Unidos hacia Cuba es hipócrita. Washington tiene plenas relaciones diplomáticas y comerciales con China, Vietnam, Arabia Saudita, Kuwait con un currículo de defensa de los derechos humanos bastante más negativo que el de Fidel Castro. Obviamente si Cuba tuviera un mercado como el de China, o petróleo de calidad, ya no habría bloqueo.

29. La mejor introducción a la Cuba actual es probablemente el libro de M. Vázquez Montalbán, Y Dios entró en La Habana, Alfaguara, 1998, Madrid. 
Para insertar el modelo cubano en el mercado mundial se busca proporcionar buenos beneficios a inversores extranjeros, descentralizando progresivamente las empresas cubanas y haciéndoles independientes en sus decisiones económicas. Se integran en la economía mundial como si fueran de propiedad privada y de gestión independiente, pero un $\mathbf{5 0}$ por ciento de sus acciones son del Estado.

El concepto oficial de democracia en Cuba pretende defender una democracia no de partidos, sino de participación popular, pero siendo muy benévolos habrá que decir que esta participación popular termina allí donde hay discrepancia con la "vanguardia revolucionaria", y que las discrepancias de la vanguardia revolucionaria terminan allí donde difieren de Fidel. Un ejemplo de ello es la sustitución de Robaina - a quien, como dicen en Cuba, "han puesto el pijama"-, pues ha desaparecido de la luz pública sin necesidad de justificación. Es muy probable que la absoluta falta de libertad de prensa, aparte de los atropellos y los crímenes del régimen, esconda en Cuba casos graves de corrupción. Otro problema, no menos grave, es que la vanguardia acaba considerándose imprescindible; cree saber lo que es mejor para el pueblo y considera que tiene el derecho de imponerlo. Fidel, por ejemplo, puede pedir a "los mandos intermedios" que no se enquisten en sus sillas, pero esto no incumbe a la vanguardia ni por supuesto a él mismo, como si estuvieran más allá del bien y del mal. No hay de momento asomo de oposición, de competencia política ni de liberalización de la información, aunque todo el mundo habla con menos miedo y critica continuamente al sistema. Sigue funcionando una estructura política leninista con núcleos disciplinados en todas las instituciones públicas. Esta estructura, muy útil para movilizar al pueblo en caso de desastre natural o de guerra, no puede mantener la cooperación permanente voluntaria de la población, sino es a través de medidas coercitivas, de prebendas y de ofertas de algún tipo de privilegio.

La "vanguardia" cubana parece mantener una especie de fe en que se van a ir agudizando los problemas del modelo neoliberal y que va a hacer falta una alternativa mundial a la economía en unas décadas. Si Cuba resiste, podrá insertarse luego mejor en una alternativa socialista global. Lo más probable es que cuando se muera Fidel, Cuba abrace el capitalismo sin más. Lo que está claro es que no hay marcha atrás y que el paradigma de la centralización socialista no resulta factible en las actuales condiciones de desarrollo económico y cultural de Cuba, y mucho menos en una perspectiva mundial. ¿Sería posible para Cuba avanzar hacia un socialismo descentralizado? ¿Podría otorgarse a las cooperativas agrícolas mayor autonomía y aumentar la propiedad social frente a la propiedad del Estado que los trabajadores no sienten como suya? ¿Podría desarrollarse un pluralismo político limitado que respetara la propiedad social de los trabajadores?"3". El socialismo de mercado podría ser la única opción para Cuba para no acabar cayendo en los brazos del capitalismo. Todos los socialistas de mercado creen firmemente que el mercado, con una propiedad mayoritariamente social o cooperativa, sin excluir en algunos casos la propiedad individual y la propiedad del Estado, es un mecanismo económico más capaz que la planificación centralizada y el capitalismo reformado para enfrentar los problemas de la sociedad mundial" .

\section{La democracia cosmopolita}

En la actualidad, una de las propuestas más sugerentes para democratizar la sociedad mundial proviene de D. Held. Frente a los socialdemócratas convencidos de que no hay alternativa al sistema de propiedad capitalista y socialistas defenso-

30. Puede consultarse aquí el interesante proyecto de J. C. Edelstein, "El futuro de la democracia en Cuba", La democracia en Cuba y el diferendo con los Estados Unidos, CEA Habana, 1995, pp. 130-148.

31. Véase J. Corominas, “¿Socialdemocracia mundial o socialismo de mercado?”, ECA, San Salvador, enero-febrero, 1998, pp. 81-95; "Hacia la construcción de un proyecto de sociedad alternativo", ECA, San Salvador, octubre, 1998, pp. 931-949; A. González, “¿Qué queda del socialismo?”, Realidad, enero-febrero, San Salvador, 1997; David Schweickart, Against Capitalism, California, Westview Press, 1996; John Roemer, A Future for Socialism, Harvard University Press, 1994; Manuel Monereo, Para que el socialismo tenga futuro, El Viejo Topo, Barcelona, 1999. Para una crítica al socialismo de mercado y la defensa de la planificación centralizada, véase el artículo de Duan Zhong Qiao, Profesor de la Universidad Renmin, Pekín, Chin, Revista Marxista Revolucionaria, Atenas, diciembre de 1998. 
res de la economía dirigida cree que es posible explorar una gestión democrática de las empresas y de la propiedad. Mientras A. Giddens está convencido de que no hay alternativa a las formas de propiedad generalizada en el capitalismo, D. Held se muestra mucho más cauto sobre el asunto. En principio considera atractivas las formas cooperativas de propiedad donde los grupos de trabajo poseen colectivamente la empresa, "pero todavía no se ha elaborado un argumento completamente convincente a favor de la propiedad cooperativa como forma de propiedad generalizada. Lo que la democracia cosmopolita prescribe es la necesidad de extender la democracia a la economía y el lugar de trabajo, pero deja la determinación del modelo institucional específico para concretar el cambio en manos del proceso de experimentación y ensayo públicos"32.

Lo más interesante de la democracia cosmopolita es que busca extender la democracia hacia arriba, hacia abajo y lateralmente al estado-nación. Contra la teoría realista predominante en la teoría política intemacional, D. Held considera que la sociedad mundial actual se encuentra sometida a una fuerte tensión entre la legitimidad democrática dentro de las fronteras del Estado y la implementación de una política de poder y fuerza fuera de esas fronteras. Los orígenes de esta tensión pueden rastrearse en la creación modema de los EstadosNación, esto es, en la implantación de la soberanía territorial promovida por los poderes europeos para consolidar los dominios nacionales. La aplicación de la estructura de las Naciones Unidas encima de este sistema tras la segunda guerra mundial, no alteró sus rasgos básicos. La carta de la ONU acentuó la función de las grandes potencias, con lo cual sus pretensiones de liderar la política internacional recibieron una nueva justificación. De hecho, desde el siglo XVIl las relaciones internacionales se han considerado como un estado de naturaleza, un continuo estado de guerra de todos contra todos fuera de todo control racional. Puesto que no depende uno de otro, cada Estado tiene la absoluta libertad para hacer lo que juzgue más conducente a su beneficio. La perspectiva hobbesiana constituye el núcleo de la teoría realista dominante en la conceptuación de las relaciones políticas mundiales. Durante los siglos XIX y XX, esta teoría apenas si ha cuestionado la soberanía del estado-nación o la dinámica de la economía mundial.

Frente al rechazo explícito de la teoría realista de aquellas concepciones que interpretan la intensificación de las interconexiones como presagio de la crisis del estado-nación modemo, D. Held argumenta que hoy no se puede asumir que los gobiernos nacionales sean el lugar del poder político efectivo. El poder político es compartido y forzado por diversos actores, fuerzas y agencias nacionales, regionales e internacionales. Algunas de las fuerzas y de los procesos más importantes que determinan las posibilidades de vida y muerte de los ciudadanos del mundo se encuentran fuera del alcance de las naciones-estado. Aunque la soberanía nacional no haya sido totalmente subvertida, las operaciones de los estados en la mundialización ven afectada de algún modo su soberanía y autonomía. En las democracias liberales, la legitimidad de la acción gubernamental depende del voto secreto e individual; pero esta legitimidad es muy problemática cuando la mayoría de ciudadanos del mundo no pueden tomar ninguna decisión política sobre los problemas que más los afectan, o cuando actores transnacionales y estados poderosos toman decisiones no sólo para su gente sino para otros. Las fronteras nacionales han marcado tradicionalmente las bases en la que los individuos están incluidos y excluidos de la participación en decisiones que afectan sus vidas. Pero si muchos asuntos importantes son excluidos de la participación ciudadana, la teoría y práctica democrática queda mucho más cuestionada.

Todas estas consideraciones llevan a D. Held a afirmar que la legitimidad de la democracia sólo puede ser redimida en un contexto transnacional mediante su radicalización. La democracia cosmopolita implica el desarrollo de capacidad administrativa y de recursos políticos independientes, a escala regional y global, como complemento necesario a las políticas locales y nacionales. Para ello es necesario crear nuevas instituciones políticas que coexistan con el sistema de estados, pero que irían más allá del Estado en aquellas esferas donde las actividades y las decisiones estatales tengan claramente consecuencias transnacionales e internacionales. Se trata no sólo de construir mecanis-

32. D. Held, La democracia y el orden global, del Estado moderno al orden cosmopolita, Paidós, 1997 , p. 312 y ss. 
mos democráticos supraestatales, sino avenidas de participación cívica en el ámbito local, regional y nacional respondiendo democráticamente a las presiones de la mundialización hacia arriba (ecología, problemas de salud, mercado mundial), hacia abajo (autonomías en México, en Europa, etc., mayores poderes municipales) y lateralmente (nuevas regiones económicas y culturales que traspasan las fronteras nacionales). La impresionante diversidad cultural e idiomática de Centroamérica y el Caribe: la Mosquitia, los garifunas, las diferentes comunidades mayas de Guatemala, los creoles, etc., son un claro ejemplo de relaciones y esferas transestatales que podrían ganar una mayor autonomía reacondicionando el modelo político de las naciones-estado.

La sociedad humana, en la actual organización política del mundo, está repartida en Estados que designan, mediante diferentes criterios, aquellos a quienes consideran sus nacionales y aquellos que no. Los extranjeros suelen estar excluidos de la participación política independientemente de sus lazos afectivos, la duración de su estancia y su contribución a la actividad productiva. En Europa se admite la participación de los extranjeros comunitarios en las elecciones municipales, pero no en las estatales. Frente al nacionalismo conservador -que suele considerar que la nación se hereda del pasado y debe ser protegida de la contaminación cultural, con todos los peligros de intole-

D. Held argumenta que hoy no se puede asumir que los gobiernos nacionales sean el lugar del poder político efectivo. El poder político es compartido y forzado por diversos actores, fuerzas y agencias nacionales, regionales e internacionales. compartible con otras lealtades paralelas. Un nacionalismo benigno y cosmopolita en que las diferentes identidades puedan sentirse cómodas y donde no haya exclusiones en el uso del voto para cuestiones que afectan a todos ${ }^{33}$.

A corto plazo, D. Held propone la reforma de las instituciones más antidemocráticas de la ONU para asignar a los países en desarrollo una voz significativa y capacidad de decisión; la creación de un tribunal mundial de los derechos humanos; la creación de una fuerza militar internacional bajo control democrático; el suministro de recursos vitales a los que ocupan las posiciones sociales más vulnerables en el mundo; la experimentación sistemática con diferentes formas de organización democrática de la economía; la democratización de la ciencia y de la tecnología, forzando a los expertos a dar cuenta de sus proyectos ante el escrutinio público. A largo plazo propone la creación de un parlamento global con capacidad de recaudación impositiva conectado a todas las regiones y naciones; la creación de un tribunal de cuestiones fronterizas; el desarrollo de una economía multisectorial y la pluralización de las pautas de propiedad y posesión; el establecimiento de un ingreso básico garantizado para todos los adultos ${ }^{34}$; la creación de un tribunal penal internacional; la transferencia de la capacidad coercitiva de los estados a instituciones regionales y globales para erradicar la guerra.

La teoría de la democracia cosmopolita es una de las pocas teorías políticas que examina, sistemáticamente, las implicaciones democráticas del hecho que las naciones-estado están sujetas a complejas relaciones mundiales. Lo que el autor encuentra más interesante de la teoría cosmopolita es que es un esfuerzo por pensar un modelo democrático que nos permita una gestión democrática en diferentes niveles tenido hasta ahora, pero donde siga siendo legítima una cierta identidad nacional más reflexiva y radical de izquierdas, que suele cuestionar toda identidad nacional con el peligro de anomía y desorientación-, lo que nos propone D. Held es una especie de nacionalismo benigno y tolerante. Un nacionalismo sin el nivel de inclusividad que ha crater

33. En este nacionalismo benigno coincide el bello libro de T. Todorov, El hombre desplazado, Taurus, Santillana, 1998.

34. Véase el interesante y exhaustivo artículo de Francisco José Martínez, "Fundamentos de la renta básica mundial", HIKA, Euzkadi, 130, 1999, pp. 25-29. 
que se entrecruzan en el mismo estado-nación. Es un modelo que se sitúa entre una concepción confederal de la relación de los estados demasiado débil para promover la intervención directa de organismos y plataformas interestatales a través de los estados, y un federalismo mundial demasiado rígido y tendente a la constitución de un estado mundial. Es, si se quiere, una reedición de la $\mathrm{Paz}$ perpetua de Kant a la altura de los tiempos. También Kant rechazaba la idea, implícita en la constitución de los estados-nación, de que la paz no llegará hasta la constitución de una república mundial, muy lejana en el tiempo, en el supuesto de que pudiera darse y que tiene precisamente a la guerra como su principal artífice. Frente a la constitución de una república mundial (Hegel), Kant propone una confederación de paz, una confederación de pueblos para evitar la guerra y para acabar con las relaciones injustas ${ }^{35}$. Los paradigmas modernos siguen pensando mayoritariamente las categorías y la acción política desde categorías hegelianas. La paz perpetua y la reconciliación universal de todos llegará al final de un largo proceso, del que tanto la colonización como la acumulación actual serían un paso necesario en el que se impondrá, por la misma dinámica de los conflictos sangrientos de la historia, un Estado y una cultura mundial. Frente a esta concepción modernizante de la globalización, la democracia cosmopolita representa una percepción nueva. No queda presa de la concepción moderna del estado-nación que, en el mejor de los casos, lleva a proyectos rígidos de estados o de federaciones mundiales o a confederaciones o entes como la ONU, demasiado débiles e incapaces de elaborar estructuras democráticas que se entrecrucen en distintos niveles. El estado-nación no desaparece, pero en su reciclaje pierde su cualidad sacrosanta.

La democracia cosmopolita no es sólo la dilatación de las prerrogativas del estado-nación hacia un nivel mundial, sino también su difusión descendente hacia los entes locales y su expansión lateral. Es perfectamente compatible con la democracia radical, alentada en nuestras latitudes por el filósofo mexicano Luis Villoro ${ }^{36}$. En esta nueva revolución democrática, capaz de integrar a grupos con intereses muy dispersos, los pueblos ${ }^{37}$, las comunidades y regiones sometidas a la uniformidad estatal adquirirían el máximo de poder de decisión sobre aquellos asuntos que les competen y podrían gestionar ellos mismos. En Centroamérica y el Caribe, por ejemplo, se conservan muchas comunidades tradicionales que la forma moderna de Estado ha considerado siempre una rémora para el desarollo. Democratizar estas comunidades significa apoyarlas, favorecer su autodeterminación y aprender de ellas para combatir el individualismo y el desamparo de la cultura occidental. Pero a la vez significa no conservarlas como un museo viviente, sino como comunidades que incorporen libremente sus antiguos valores. La revolución democrática afectaría también a las asociaciones pequeñas como las familias, las escuelas, los comités de barrios y los centros de producción y las asociaciones de ciudadanos. "Un socialismo democrático no consiste, en efecto, en la expropiación de los medios de producción por el Estado sino en un proceso de signo contrario: es la meta final de una democracia en la que el pueblo, en los lugares en que trabaja, participa activamente en las decisiones que le afectan y en los beneficios de su labor"3* . Desde esta perspectiva, el socialismo, si algún futuro ha de tener, pasaría por la radicalización de la democracia y no por su abolición.

La objeción que suele surgir ante este tipo de planteamientos es que se trata de una utopía irrealizable. Pero cuando surgió la idea de Estado secular de la cabeza de Hobbes y otros, tenían como telón de fondo un pasado de circunstancias históricas menos prometedoras aún que las del momento presente y, 200 años más tarde, su formulación se había convertido ya en el elemento dominante de la organización política mundial. Es muy probable que el escenario del próximo siglo sea el de una parte del mundo altamente organizada (los países ricos actuales) y tierras de nadie o de combinaciones entre gángsters y señores de la guerra en zonas de África, Asia (Afganistán) y América Latina. De hecho, el intento de numerosas regiones del mundo de imitar el estilo de vida, la utilización de recursos y los modelos de consumo occidental y la imposibilidad de universalizarlos por sus costes

35. I. Kant, La paz perpetua, Aguilar, 1966. p. 65.

36. Véase Luís Villoro, El poder y el valor, fundamentos de una ética política, FCE, México, 1997.

37. Luís Villoro considera que los Cabildos, en la tradición hispánica, han sido siempre el centro de las libertades ciudadanas en su lucha contra el absolutismo. Ibid, p. 377.

38. Ibid., p. 354 y ss. 
medioambientales, podrían tender a promover este escenario y es muy cínico recomendar, como hacen los informes del PNUD, un desarrollo sostenible para los pobres sin cambiar las pautas de consumo y las formas de vida de los ricos. En cualquier caso, cualquier intento de asumir una utopía realista del tipo que propone $D$. Held debe partir del esfuerzo por enfrentar las cosas como son, pero para no quedar atrapados en la mera reproducción de las cosas del pasado, deberemos contemplar si puede evaluarse a la luz de algún criterio ético.

\section{8. ¿Existe algún criterio ético mundial no etno- centrista?}

El problema que aquí nos planteamos es si puede buscarse un punto mínimo de acuerdo universal sobre una gestión democrática de la sociedad mundial y qué recursos nos brindan las tradiciones éticas hoy en día. Más concretamente, la pregunta que nos hacemos es si este mínimo debe extraerse siempre desde la "eticidad" inmanente a un determinado contexto histórico-social, o si es posible apelar a un criterio "trascendental", válido para todos y que contraste siempre con la realidad concreta. Por ejemplo, se podría plantear que el individuo debe asumir como valores irrenunciables los de la comunidad en que vive. Así, una comunidad musulmana, un comunidad hindú o una comunidad quiché -que vivan en alguna urbe de Estados Unidos o de Europa - deberían asumir valores como la autonomía, la igualdad formal de todos los seres humanos, que suelen formar parte de la ética cívica occidental-latina, pero también la competitividad y el irrespeto por la naturaleza. Y a la inversa, un grupo de occidentales que vivan en una cultura musulmana, hindú o quiché deberían asumir valores como la importancia de la comunidad, el respeto a todo tipo de vida, pero también las jerarquías que establece la tradición y las diferencias de género. ¿La democracia -aún en su forma más ideal y utópica - es exclusivamente una construcción occidental que otras culturas no tienen por qué compartir, o podría discutirse, apelando a algún criterio ético transcultural, qué es bueno para la humanidad y qué no en los regímenes políticos que mantienen las diferentes culturas? Las respuestas a estas cuestiones han cruzado el debate de la entera historia de la filosofía y siguen siendo cruciales en los debates éticos académicos.

Mas allá del etnocentrismo y del relativismo cultural se encuentra la propuesta intercultural ${ }^{34}$ de entablar un diálogo permanente entre los que comparten distintos bagajes culturales, de forma que decidan conjuntamente qué humaniza y qué deshumaniza. Los proyectos de filosofía intercultural critican tanto el esencialismo universalista de la filosofía occidental que pretende constituirse en árbitro de las culturas, como el culturalismo, que termina en un solipsismo cultural y abogan por aprovechar todas las formas de diversidad, hibridismo y mestizaje cultural que no creen desigualdad económica y de derechos, pero para ello se ven forzados a apelar a algún tipo de invariante humano transcultural ${ }^{41}$. Justo la investigación de estos invariantes humanos, si es que se dan, es lo que me interesa plantear porque, por mínimos que sean, podría jugarse en ellos la exigencia de un diálogo intercultural en lugar de su rechazo y la posibilidad de desarrollar una ética política mundial. Dadas las limitaciones del artículo, me limitaré al planteamiento de cuatro autores contemporáneos que, de algún modo, indagan la posibilidad de establecer una invariante ética universal noetnocéntrica. Se trata del pragmatismo de Rawls, de la ética de la liberación de Dussel, de la ética del discurso de Apel y de la ética praxeológica de Antonio González. Los cuatro autores coinciden en el esfuerzo filosófico por escapar del relativis-

39. R. Fornet-Betancourt, Filosofia intercultural, México, 1994.

40. "La filosofía intercultural niega la existencia supracultural de «universales culturales» pero sigue defendiendo la existencia transcultural de invariantes humanos". Josef Estermann, Filosofia andina, estudio intercultural de la sabiduría autóctona andina, Ecuador, 1998, p. 38. 
mo o de un contextualismo extremo, que acabaría afirmando que estos mínimos éticos universales sólo se pueden alcanzar a partir del modelo de asimilación o de conversión de otras culturas a la cultura y a la forma de vida propia.

Rawls busca una concepción de la justicia que pueda ser compartida por los ciudadanos como un fundamento para un acuerdo político razonado, informado y democrático. Un acuerdo sobre el que todos puedan converger más allá de una u otra concepción del bien. El mismo J. Rawls ha calificado su Teoria de la justicia como un constructivismo kantiano. Es decir, lo único que pretende es establecer una conexión adecuada entre la concepción kantiana de la persona - como ser libre, racional y autónomo- y unos primeros principios de justicia por medio de un procedimtento de construcción ${ }^{41}$. El experimento mental que nos propone Rawls para recuperar constructivamente a Kant es el de abstraernos de las relaciones de poder, clase y económicas existentes para descubrir las condiciones del go-

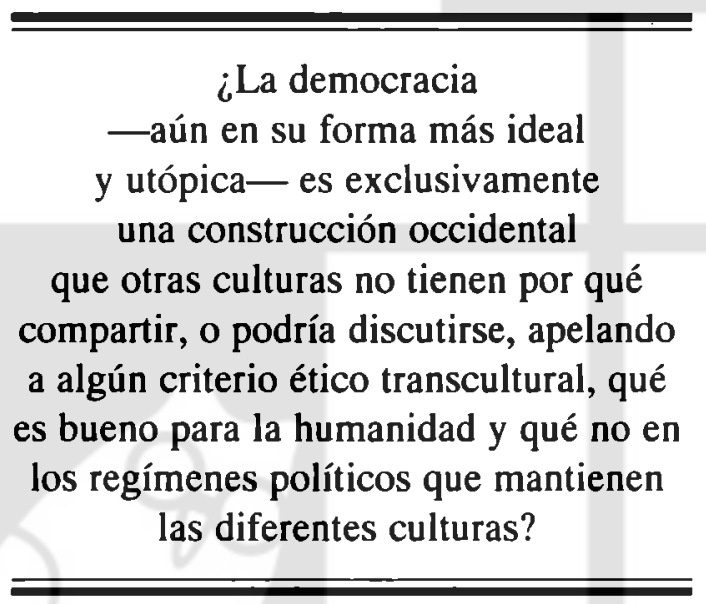

gar de origen, la raza, el género y la clase y no aceptaríamos una sociedad que no estuviera abierta a la deliberación. En segundo lugar, se rechazaría la no-autonomía, la producción y distribución asimétrica de perspectivas de vida, que limitan y erosionan la posibilidad de participación política. El principio de autonomía como capacidad de autodeterminarse, de ser conscientes y reflexivos, se establecería como base constitutiva del derecho público democrático y, en tercer lugar, se rechazarían los prejuicios que suele comportar un reparto desigual del poder $r^{2}$. Frente a la acusación de que al recurrir al concepto de persona kantiano en su fundamentación de los principios de justicia parece implicar una interrupción dogmática $y$ decisionista del proceso de fundamentación, J. Rawls se irá separando del planteamiento de Teoría de la justicia para acercarse a los del liberalismo político. D. Held sigue básicamente el planteamiento pragmático del segundo Rawls y es, a mi modo de ver, una de las principales deficiencias de bierno legítimo. En esta discusión ideal entre distintos individuos cubiertos por un velo de ignorancia sobre su situación social, económica y cultural real sólo es posible un único tipo de compulsión: La fuerza del mejor argumento. ¿Qué conclusiones se sacarían en este diálogo ideal?

En primer lugar, se establecería la incompatibilidad de la democracia con la desigualdad grave, el apartheid y el racismo, pues ninguno de estos fenómenos sería aceptado por todos en una deliberación ideal en la que nadie sabe cuál es su estatus real ni si le va a tocar ser esclavo o negro. Si no conociéramos nuestra situación futura, rechazaríamos las asimetrías del poder provenientes del lu- su propuesta. El experimento mental sólo tiene sentido en sociedades que ya parten de una tradición democrática liberal, y con esta falta de pretensión de universalidad se desposee el experimento mental de Rawls de su fuerza crítica original tendiendo a legitimar, de nuevo, la praxis de los paises ricos que son los que ya han asumido un compromiso previo con la democracia ${ }^{43}$.

La llamada "ética del discurso" de K. O. Apel cree encontrar un criterio ético transcultural implícito en todo acto lingüístico. Incluso el escéptico moral cuando argumenta presupone siempre ciertas normas que no pueden ser negadas sin cometer una "contradicción performativa". En todo acto

41. J. Rawls, Teoría de la justicia, FCE, México, 1978.

42. Entendemos el poder al modo de A. Giddens, M. Foucault, D. Held y A. González como capacidad de los agentes, las agencias y las instituciones sociales para transformar su ambiente social y físico con los recursos y fuerzas que moldean este ejercicio. El poder puede también expresarse cuando los agentes y las inslituciones parecen no hacer nada. Se trata siempre de un fenómeno relacional que atraviesa toda vida publica y privada.

43. D. Held, op. cit., p. 229. 
lingüístico estaría implícito una pretensión de verdad que anticiparía el ideal de un acuerdo o consenso universal de los seres humanos sin coacción. Los actos de habla de todos los seres humanos entrañarían un principio deontológico a priori, que K.O. Apel formula así: "obra solo según una máxima de la que puedas suponer que las consecuencias que resultaran de su seguimiento universal para la satisfacción de los intereses de cada uno de los afectados, pueden ser aceptadas sin coacción por todos los afectados en un discurso real" muchísimas críticas de la que ha sido objeto la propuesta de K.O. Apel, destacaría la crítica en el sentido de que la propuesta apeliana no es apta para criticar en pie de igualdad a todos los estilos de vida existentes en las diferentes "comunidades reales de comunicación". Así, no es extraño que ante la imposibilidad ecológica de universalizar la forma de vida occidental, Apel sugiera que los pueblos pobres del mundo deberían buscar un camino propio de desarrollo, sin poner en peligro la supervivencia humana en el planeta; mientras Ellacuría considera, desde una perspectiva kantiana, que es la misma forma de vida occidental la que es inmoral por no universalizable y la que habrá que transformar ${ }^{45}$. Según A. González, esta disparidad entre Apel y Ellacuría no es meramente accidental, sino que refleja una dificultad constitutiva de las éticas del discurso: la dificultad de criticar aquellas formas de vida que hoy por hoy hacen posible las instituciones de diálogo realmente existentes. El problema estriba en que "si la ética del discurso quisiera criticar radicalmente a la forma de vida occidental, cometería una especie de "contradicción performativa ${ }^{46}$, pues tendría que criticar justamente a una de sus condiciones de posibilidad"47.

La novedad más importante de la ética de la liberación de E. Dussel respecto a la ética del discurso, es el intento de completar la formalidad de la misma con un principio material universal más o menos próximo a las éticas comunitaristas. Este principio exige la producción y la reproducción de la vida en comunidad, de modo que se podrá decir que un acto cualquiera tendrá pretensión de bondad cuando cumpla las condiciones universales (materiales y formales). Ambos principios se complementarán con una racionalidad estratégica (prudencia) y con un principio crítico, que sería el más propio de una ética de la liberación, que afirma que, dado que ningún acto puede ser perfecto, es desde sus efectos negativos en las víctimas que tendrá que ser valorado. Dussel ha señalado que en cualquier comunidad de comunicación hay siempre personas que están excluidas, que no toman parte en el diálogo y se encuentran relegadas de los consensos que realmente se alcanzan. La ética del discurso sería una reflexión elaborada en el contexto de las instituciones democráticas del primer mundo; mientras que la ética de la liberación trataría de representar la perspectiva de los empobrecidos y excluidos. $Y$ es que, según Dussel, los verdaderos impulsos éticos no surgen en el diálogo con aquéllos que comparten los mismos intereses y categorías, sino ante el rostro demacrado de aquellos que han sido marginados por el sistema. Por ello, el verdadero punto de partida de la ética no es el diálogo con los iguales, sino la interpelación por las víctimas.

Ciertamente la propuesta dusseliana de complementar el principio material, formal, pragmático y teleológico se muestra, en principio, más vigorosa para juzgar y orientar los actos humanos que las otras propuestas aquí reseñadas. Pero su mayor poder discriminatorio parece ir unido a una mayor constructividad filosófica y, en consecuencia, a una universalidad menos obvia para cualquiera. Al recoger el principio material de las éticas vitalistas y comunitaristas, el principio formal de las éticas del discurso, el principio de factibilidad de las éticas pragmáticas y el principio crítico de inspiración levinasiana, no sólo recoge lo mejor de cada una de estas elaboraciones éticas, sino

44. K.O. Apel, "¿Límites de la ética discursiva?”; A. Cortina, "Epílogo", Razón comunicativa y responsabilidad solidaria: Ética y política en K.O. Apel, Salamanca, Sigueme, 1985, p. 251.

45. A. González, "Fundamentos filosóficos de una civilización de la pobreza", ECA, 583, mayo, San Salvador, 1997, p. 420.

46. K. O. Apel llama contradicción performativa a la contradicción entre las partes proposicional y pragmática de un acto de habla argumentativo. La contradicción performativa ejemplar es la que niega las pretensiones de validez del habla (sentido, verdad, corrección, veracidad), tal como ocurriría si afirmásemos: "Asevero con esto [pretendo sentido (parte performativa)] que no tengo ninguna pretensión de sentido [dimensión proposicional]". K.O. Apel, Estudios éticos, Ed. Alfa Iberia, Barcelona, 1986, p. 20.

47. A. González, "Fundamentos filosóficos de una civilización de la pobreza", op. cit., p. 420. 
también sus problemas. Así, por ejemplo, el principio material lo deriva Dussel de la constatación antropológica de que el ser humano es el único ser viviente responsable de su propia vida ${ }^{48}$. Ello implicaría la obligación universal de producir, reproducir y desarrollar la vida humana concreta de cada sujeto ético en comunidad. Este principio constituiría un principio a priori material universal y sería el principio fundamental, aunque no suficiente, de una ética de la liberación, es decir, de una ética que intenta justificar filosóficamente las luchas de los oprimidos. Ciertamente la vida humana marca límites y tiene exigencias propias. "Se necesitan alimentos, casa, seguridad, libertad, soberanía, valores, identidad cultural y plenitud espiritual"49, pero estas exigencias dependen de si quiero seguir viviendo. Precisamente porque la vida está entregada a nuestra responsábilidad tenemos que decidir también si queremos vivir, no se ve porque el hecho de que la vida esté entregada a nuestra responsabilidad exige que la conservemos.

E. Dussel demuestra que la vida humana es la condición absoluta de la ética, pero de ello no se sigue que la vida humana imponga como principio universal el deber de desarrollarla y preservarla, y mucho menos, y esto ya es un problema que afecta a todos los vitalismos, que obligue a preocuparme y a responsabilizarme de la vida de los demás. En esta renovada ética de la liberación, el caso límite ya no sería el del cínico, sino el del suicida: el que pretendiera justificar la muerte, el asesinato o el suicidio individual o colectivo ${ }^{511}$ cometería una especie de contradicción performativa. A mi modo de ver, lo único que nos muestra $\mathrm{E}$. Dussel es que la apuesta por la muerte en el límite elimina la ética, pero no se comete con ello una contradicción performativa. Se cometería una contradicción performativa sólo si se mostrara que, por el mero hecho de vivir, estoy obligado a reproducir y desarrollar mi propia vida y la de los demás, pero esto es justamente lo que no queda claro. Una cosa es que la vida sea condición de posibilidad de la ética, otra que del mero vivir humano pueda desprender una conminación a seguir viviendo y a defender la vida humana, convirtiéndose esta exigencia en un criterio de evaluación ética.
En la ética praxeológica de A. González encontramos un dinamismo (es lo que podemos llamar actos racionales) en el análisis de nuestros actos mismos, que nos lleva a interrogarnos sobre las actuaciones posibles e incluso a crear nuevas actuaciones. Frente a la obligación y el mandato de la actuación y de sus mecanismos a menudo mecánicos y repetitivos, los actos racionales cuestionan, critican, crean, inventan y a menudo enfrentan a los individuos con las categorías vigentes. La posibilidad misma de renunciar a este dinamismo, de encerrarse en la propia cultura, tradiciones y consensos, de no salir nunca del ámbito de la actuación, de actuar irracionalmente, es una posibilidad otorgada por este dinamismo. Pero sea cual sea la contravención moral de la actividad racional, nosotros estamos siempre también recodificando nuestra conducta y sometiéndola a nuevos regímenes morales.

La tendencia universalizadora o fuerza de la razón detectable en el análisis de los actos racionales humanos nos lleva, de algún modo, a considerar los derechos de los no-nacidos, de los fetos, de los moribundos y de los disminuidos más allá de todo consenso, contrato y utilidad. Esta fuerza puede llegar a trascender no sólo las fronteras del propio clan, clase, nación o comunidad, sino incluso las fronteras de la especie humana. La marcha de la razón sentiente puede llevarnos hasta compenetramos con los animales y los demás seres vivos ${ }^{51}$ y a ponemos, de algún modo, en su lugar. De ese modo, el impulso para respetar a los animales y las plantas no se agota en el interés por la supervivencia de la humanidad, y puede llevarnos inclusive más allá de los límites de los intereses de la humanidad. La ventaja de A. González sobre la ética del discurso y la ética de la liberación es que su carácter trascendental se encuentra en los actos mismos, sin tener que remontarse a las condiciones de posibilidad ni a supuestas instancias que los posibilitan mucho menos obvias para cualquiera que los actos mismos. La ética praxeológica no tiene necesidad de privilegiar un tipo de actos, los actos lingüísticos, ni de construir una ética que aúne lo mejor de cada una de las tradiciones filosóficas actuales. La universalidad de la ética

48. E. Dussel, Ética de la liberación en la edad de la globalización y de la exclusión, op. cit., p. 138 y ss.

49. Ibid., p. 129.

50. Ibid., p. 141.

51. Zubiri, X., Inteligencia y razón, Madrid, 1983, p. 250. 
praxeológica parece así mayor que la del discurso y la de la liberación, aunque respecto a la última se muestra mucho más abierta y sujeta a construcciones ulteriores.

Este peculiar empuje universalizador de los actos racionales constituiría la invariante humana supracultural, que el análisis filosófico es capaz de detectar. La universalidad, en esta perspectiva, es justo lo contrario del intento etnocéntrico de imponer mis propias categorías a los demás. Cuando me encuentro con otros que no comparten mis intereses y categorías, este dinamismo me invita a ponerlos en el mismo plato de la balanza que mis propios intereses y a distanciarme de mis propias categorías. Este dinamismo nos lleva a trascender, de algún modo, las culturas concretas y a formular la "regla de oro" presente en tantas religiones y culturas: No puedes querer para otros lo que no quieres para ti. Es por este dinamismo que cabe la esperanza de un diálogo intercultural y de una democracia que sea algo más que el consenso impuesto por los poderosos y el dominio occidental del mundo ${ }^{52}$. Toda ética política es posible por esta capacidad humana de acercarnos a un punto de vista imparcial. Para ello no se requiere hacer de lado los intereses individuales y de grupo, sino solamente aquellos intereses y aquellas formas de vida excluyentes con las demás ${ }^{53}$. La lucidez no consiste sólo en apreciar la ruindad y el abismo que acecha siempre a las mejores leyes e instituciones políticas, sino también esta pizca de grandeza que habita en el corazón de los humanos capaz de encauzar las aguas más turbias.

San Salvador, enero de 2000.

52. Puede verse aquí la interesante reflexión de Adela Cortina para la constitución de una ética mínima y una ciudadanía mundial. Hasta un pueblo de demonios, Ética pública y sociedad, Taurus, Madrid, 1998. p. 61. Y también las palabras de I. Kant escritas en el siglo XVIII y que hoy, en el S. XXI, resultan perentorias: "La comunidad entre los pueblos ha llegado a tal situación que una violación de la ley en cualquier lugar de la tierra es sentida por todos. Así que la idea del derecho de ciudadanía mundial no es fruto de una imaginación fantástica y exagerada acerca del derecho, sino un complemento necesario del código no escrito del derecho político y de las naciones, que de esta manera llega a ser el derecho público de la humanidad, favorecedor de la paz perpetua". I. Kant, op. cit., p. 72.

53. Véase Luís Villoro, El poder y el valor, fundamentos de una ética política, FCE, México, 1997, p. 236 y ss. 